\title{
Greater Reliance on Major Customers and Auditor Going Concern Opinions
}

\author{
Dan Dhaliwal (deceased) \\ Eller College of Management \\ University of Arizona \\ Paul N. Michas \\ Eller College of Management \\ University of Arizona \\ 1130 E. Helen St. \\ Tucson, AZ 85721 U.S.A. \\ paulmichas@email.arizona.edu
}

\author{
Vic Naiker \\ The University of Melbourne \\ 198 Berkeley Street, Melbourne \\ Victoria 3010, Australia \\ vic.naiker@unimelb.edu.au \\ Divesh Sharma \\ Coles College of Business \\ Kennesaw State University \\ Burruss Building 202 \\ 100 Chastain Rd. \\ Kennesaw, GA 30144 U.S.A. \\ dsharma2@kennesaw.edu
}

We thank Miguel Minutti-Meza (Editor), two anonymous reviewers, Jere R. Francis, Dana Hermanson, workshop participants at the University of Arizona, the University of Miami and the 2014 AAA Midyear Auditing conference in San Antonio, TX for their helpful comments on previous drafts of the study. We also thank current and former auditors for their insights on audits of major customers. Paul Michas thanks the University of Arizona for research support. Vic Naiker thanks the University of Melbourne for research support. Divesh Sharma thanks Kennesaw State University for research support. An earlier version of this paper was titled "Major Customer Reliance and Big 4 Auditor Going Concern Decisions." All data are publicly available.

All three remaining authors thank Dan Dhaliwal for his very special and unique mentorship and leadership over the years. Your presence and influence are missed every day. 


\title{
Greater Reliance on Major Customers and Auditor Going Concern Opinions
}

\begin{abstract}
In this study we predict and provide evidence that distressed firms that rely more heavily on major customers for sales have a comparatively higher incidence of receiving going concern opinions (GCOs). Moreover, we find that the effect of increased reliance on major customers is driven by firms that are more distressed. We also theorize that variations in key characteristics of the relationship between distressed firms and their largest major customer are incrementally linked to GCOs, and present evidence consistent with this. Specifically, we find that the effect of greater reliance on major customers is driven by firms that are relatively smaller than their largest major customer. Additionally, we find that greater reliance on major customers is positively (negative) associated with GCOs when firms are in a shorter (longer) relationship with their major customer and when firms have a different auditor to (same auditor as) the largest major customer. Overall, our study indicates that supply-chain relationships are relevant business risks associated with auditors' going concern assessments.
\end{abstract}

Keywords: going concern, major customer, financial distress, customer reliance, sales dependence

JEL code: M49 


\section{Introduction}

This study examines whether the issuance of going concern opinions (GCOs) is related to distressed supplier firms' greater reliance on major customers and whether this association is influenced by supply chain characteristics. ${ }^{1}$ Regulators have long recognized the potential business risks associated with firms' reliance on major customers for sales, and thus the importance of suppliers disclosing this information to investors. Statement of Financial Accounting Standards (SFAS) No. 131, Disclosures about Segments of an Enterprise and Related Information, requires firms to disclose the revenues sourced from customers that generate at least 10 percent of consolidated revenues (FASB 1976; FASB 1997). ${ }^{2}$ SFAS No. 131 uses the term "major customer" to refer to a specific customer meeting this threshold, which is the definition we adopt in this study. The Securities and Exchange Commission's (SEC) implementation of SFAS 131 through Regulation S-K Item 101 (SEC 2015) signifies the relevance of major customer disclosures to assessing risks in suppliers' revenues and profitability.

While the majority of prior studies have focused on how financial ratios and auditor characteristics affect going concern assessments (e.g. Carson et al. 2013), there is a paucity of studies on how auditors' going concern judgements are affected by their consideration of firmspecific business risks, as reflected in corporate disclosures (e.g., Behn et al. 2001; Bruynseels and Willekens 2012; Bruynseels et al. 2011). Auditing standards suggest the extent and conditions of suppliers' reliance on major customers can provide information to assess future business risks (ISA

\footnotetext{
${ }^{1}$ Hence, our study is based on a sample of supplier firms that have at least one major customer, and the main empirical construct of interest is the extent of their level of major customer concentration.

${ }^{2}$ SFAS 131 followed FASB Summary of Statement No. 14 by requiring that "if 10 percent or more of the revenue of a company is derived from sales to any single customer, that fact and the amount of revenue from each customer must also be disclosed" (FASB 1976). However, the standard does not require that the name of the specific major customer be disclosed. Therefore, this customer identification in the reporting is voluntary and many companies choose not to disclose the major customer name.
} 
315) with implications for GCOs (AICPA 2006; PCAOB 2003). ${ }^{3}$ As such, information on the reliance of major customers can represent observable financial disclosures that are correlated with unobservable auditor's judgments about factors affecting the likelihood of GCOs.

However, a distressed firm's reliance on major customers may either mitigate or exacerbate the firm's going concern risks. One view is that greater reliance on major customers can signify the inability of firms to diversify their customer base. This can provide major customers with greater leverage in extracting price concessions and other benefits (Schumacher 1991; Snyder 1996), which may compound financial stress on suppliers. Indeed, several studies document the adverse effects of major customers on the performance of suppliers (e.g., Cohen and Frazzini 2008; Gosman and Kohlbeck 2009; Hertzal et al. 2008; Jorion and Zhang 2009; Pandit et al. 2011; Patatoukas 2012). The greater reliance on major customers could in fact result in a no-win situation for distressed suppliers as the adoption of a tougher bargaining stance can lead to major customers switching to suppliers with favorable concessions or opting to produce products internally. These arguments underline the business risks associated with distressed suppliers relying heavily on major customers, exacerbating the likelihood of auditors issuing GCOs to such suppliers.

An alternate view is that greater reliance on major customers can mitigate the likelihood of GCOs for distressed suppliers because major customers can have embedded ties with their suppliers as a result of more social interactions and network ties (Yli-Renko et al. 2001). These ties enhance communication and coordination resulting in suppliers developing expectations and systems that are compatible with their major customers (Ak and Patatoukas 2016; Yli-Renko et al. 2001) These benefits can improve the performance of suppliers (Kim and Henderson 2015; Lanier et al. 2010) and make it easier for distressed suppliers to retain major customers in comparison to

\footnotetext{
${ }^{3}$ Our review of auditors' reasons for issuing a GCO in Audit Analytics (as of May 2018) does not reveal any mention of loss of a major customer. However, these reasons do include declining revenues, which can stem from the loss of a major customer.
} 
retaining a large number of smaller customers that collectively produce the same amount of sales (Irvine et al. 2016). Major customers may also have incentives to cooperate with distressed suppliers to minimize disruptions to their own production (Swinney and Netessine 2009).

We posit that the effect of greater reliance on major customers on GCOs can be better understood by considering several supply chain characteristics: supplier's financial distress, supplier's size, supplier's size relative to major customer, duration of the supplier-major customer relationship, and the supplier and major customer sharing the same auditor. First, greater supplier financial distress can trigger a positive relationship between greater reliance on major customers and GCOs if auditors perceive major customers are taking advantage of the distressed supplier's financial condition and/or a higher risk of suppliers' inability to retain major customers (Lanier et al. 2010). However, major customers may financially support distressed suppliers to reduce supply-chain interruptions (Fee et al. 2006), which auditors may perceive is a GCO mitigating factor. Second, larger suppliers are likely to face lower going concern risks because they can retain major customers through delivering innovative products and services (e.g., Shefer and Frenkel 2005; Wagner and Hansen 2005), and their stronger information environments and governance structures (e.g., Lang and Lundholm 1993; Laing and Weir 1999; Ge et al. 2016) can facilitate better access to funding for generating new sales to weather the potential loss of a major customer.

Third, the relative size of suppliers to major customers reflects the potential effects of bargaining power. Suppliers that are relatively smaller can be compelled to provide price concessions, conform to stringent customer requirements, and attract less financial support from such customers (e.g., Iozzi and Valletti 2014; Snyder 1996). Hence, we expect a higher exposure of relatively smaller suppliers to GCOs when they rely more heavily on major customers. We consider the impact of the fourth and fifth supply chain characteristics (relationship duration and 
auditor sharing with major customers) without directional predictions. While longer relationships between suppliers and major customers engender mutual commitments and integration of information and logistics (e.g., Bauer et al. 2018; Dion et al. 1995), such relationships can also limit suppliers' flexibility to diversify their customer base and expose them to rent extraction (Lanier et al. 2010). Finally, when an audit firm audits both a supplier and its major customer, the auditor will gain access to more private supply chain relationship-specific information on risks (mitigating factors) that can increase (alleviate) suppliers' exposure to going concern risks.

We find that firms disclosing major customers rely on their largest major customer for around 30 percent of their total sales, signaling a risk of customer dependence (e.g., inability to raise prices, change sales strategy, or the inherent risk of losing this customer). Our regression results indicate a positive relationship between greater supplier reliance on major customers and auditors' propensity to issue a GCO (over a sample of distressed firms, which form the most salient sample for analyzing GCOs in the literature). This finding is economically significant. The mean incidence of GCOs in our sample is $7.64 \%$. Using a measure of the percentage of sales to the most important customer, we find that the incidence of GCOs marginally increases from 6.86 percent to 8.42 percent (a 22.7 percent increase) when sales to the most important customer moves from 10.2 percent to 51.5 percent (i.e., one standard deviation below to above the mean value). These values are often much larger in the sub-sample analyses we perform. We also find that the relationship between greater supplier reliance on major customers and GCOs is heightened when suppliers are exposed to higher levels of financial distress. While we do not find that the effect of greater reliance on major customers varies with the size of the supplier alone, we find that suppliers are more likely to receive a GCO when they rely more heavily on relatively larger major customers (as compared to their own size). We also find a positive (negative) relationship between greater 
reliance on major customers and GCOs for suppliers in shorter (longer) relationships with major customers and suppliers that use a different (the same) auditor as their largest major customer. Our main findings on the effect of greater reliance on major customers are robust to numerous sensitivity checks including PSM analyses and considering first-time GCOs. We also conduct several additional analyses to extend our main tests.

Overall, our results suggest that auditors view distressed suppliers to have higher exposure to going concern risks when they rely more heavily on their major customers, particularly when suppliers are relatively smaller, in shorter relationships with major customers, and employ a different audit firm than major customers. These findings suggest that auditors are evaluating such suppliers to have greater exposure to going concern risks due to major customers extracting concessions, switching suppliers, and/or not attracting major customer financial support. Our results based on the identity of audit firms suggest that auditors are more likely to identify going concern mitigating factors when they audit both the supplier and its major customer.

Our study contributes to and extends the supply chain literature (e.g., Ak and Patatoukas 2016; Hertzal et al. 2008; Huang et al. 2016; Irvine et al. 2016; Jorion and Zhang 2009; Patatoukas 2012) by providing the first evidence on auditors' tendencies to issue a GCO when distressed firms rely heavily on their major customers and on the key conditions that influence this relationship. Krishnan et al. (2018) find that auditors are not likely to issue GCOs to firms that rely more heavily on major customers. However, their GCO analyses are based on a sample that includes (1) both pre-SOX and post-SOX observations, and (2) firms that are not financially distressed. Our sample period commences in 2002 to account for the effects of SOX on going concern assessments (Fargher and Jiang 2008). More importantly, our study focuses on financially distressed firms only, 
which is pertinent to auditors' assessments of going concern uncertainties (Hopwood et al. 1994). ${ }^{4}$ Additionally, in contrast to Krishnan et al. (2018), we show that our findings are robust to alternative proxies of the reliance on major customers and to alternative design choices (e.g., PSM analyses, focusing on first-time GCOs), which provides us with a stronger basis for assessing the impact of greater reliance on major customers on auditor going concern assessments.

We further contribute to the supply chain and auditor reporting literatures by providing insights into how factors such as the financial condition of suppliers, the relative size of suppliers to their major customers, duration of the supply chain relationship, and being audited by the same audit firm affect auditors' evaluations of going concern uncertainties for suppliers that rely more heavily on major customers. Our findings also extend the emerging body of research on how auditor going concern assessments are affected by information contained in corporate disclosures as well as key financial ratios (Bruynseels and Willekens 2012; Bruynseels et al. 2011). In doing so, we respond to Carson et al.'s (2013) and Donovan et al.'s (2014) call for more audit research in settings where auditors' access to private information would be salient in assessing the going concern uncertainties associated with information reflected in corporate disclosures.

Our findings suggest that relationships between distressed suppliers and major customers are considered by auditors who have access to relatively more contractual and transactional information about these relationships than capital market participants. Given this disparity in access to pertinent information, our findings highlight the importance of required disclosures about customer concentration and the auditor's consideration of business risks in GCOs. For example, our findings support the initiatives of the FASB and SEC to enhance public disclosure of

\footnotetext{
${ }^{4}$ Similar to prior going concern studies, we find that adopting this standard restriction reduces our sample size by around 50 percent. However, we also find that our results are unaffected when we include firms that are not distressed. We find that our results remain robust to controlling for alternative measures of financial distress and other variables such as misstatements, debt maturity, and capital intensity that appear to render the result for greater reliance on major customers to be insignificant in Krishnan et al. (2018).
} 
information on major customers, and of the PCAOB (2003), AICPA (2006), and IAASB (2009) codifying auditors' consideration of potential loss of major customers. Since some private information about distressed major customers that auditors have access to is sensitive and not publicly disclosed (e.g., credit payment histories, contractual terms and conditions, special trade requirements, and aging schedules), our study paves the way for future studies to elicit non-public information on the effectiveness of firms' customer management practices and examine how such practices affect the relationship between greater reliance on major customers and GCOs.

\section{Background and Literature}

\section{The impact of greater reliance on major customers on going concern assessments}

While prior research suggests that auditors rely heavily on key financial ratios to make going concern assessments (Bruynseels and Willekens 2012; Chen and Church 1992), auditing standards are evolving to place greater emphasis on the potential role of events and conditions reflected in observable disclosures (Bruynseels and Willekens 2012; Bruynseels et al. 2011). In line with this view, several prior studies show how the likelihood of GCOs is affected by information from corporate disclosures relating to management strategic initiatives (Bruynseels and Willekens 2012; Bruynseels et al. 2011), debt default or debt restructuring (Chen and Church 1992), and issuance of additional equity and debt (Behn et al. 2001). The shift towards guiding auditors to consider a wider range of risk factors to improve their going concern assessments has been complemented by other regulatory views (PCAOB 2012).

SAS No. 59 and AU 341 provide guidance for auditors to consider, among other things, the economic consequences associated with the loss of a major customer as an indicator of a going concern problem (AICPA 2006; PCAOB 2003). In line with this view, Arnold and Edwards (1993) report that audit managers and partners rank the evaluation of risks associated with losses of major 
customers as one of the top-four going concern considerations. Ference (2015, p. 21) advises auditors to "Be alert to changing economic conditions that can affect the client [supplier] or its major customers..." when assessing going concern. Supply chain duration studies (e.g., Fee et al. 2006; Raman and Shahrur 2008) suggest that the risk of losing a major customer is higher for financially distressed firms. Our discussions with several current and former audit partners, managers, and seniors confirm that auditors consider the risks associated with major customers, including the risk of potentially losing major customers, in their going concern assessments. ${ }^{5}$

However, a distressed supplier's reliance on major customers for sales can either exacerbate or mitigate the going concern risks of the supplier. Consistent with prior going concern studies, we frame our arguments on the potential impact of greater reliance on major customers based on financially distressed suppliers as such firms are more prone to failure. On the one hand, major customers generate significant revenues and operational benefits that may favorably affect going concern assessments of such suppliers. Prior studies suggest that suppliers are more likely to have embedded ties with major customers than with smaller customers (Granovetter 1985; Uzzi 1996). Such ties can manifest through social interactions (Yli-Renko et al. 2001) that allow the suppliers to gain a deeper understanding of the major customer's operations and structures (Dyer and Singh 1998; Lane and Lubatkin 1998). These interactions and knowledge can enhance communication, trust and coordination, and lead to suppliers developing expectations and systems that are compatible with those of their major customers (Ak and Patatoukas 2016; Yli-Renko et al.

\footnotetext{
${ }^{5}$ For example, a former auditor at a Big 4 firm stated, "Our audit team always had to consider the risks and benefits of a client's [supplier's] major customer portfolio when evaluating their going concern status. During our fieldwork we would review contracts with large customers and discuss with management the likelihood of a significant customer loss that could affect their ability to continue operations in the future..." A former partner said "At my firm, there was an entire section of the receivables section of the audit program dedicated to major customers and whether or not the firm was "at risk" with a concentration of credit risk in a few large customers (i.e., if they went bankrupt, would the firm also go bankrupt)." A CPE audit training manual states on risks of inadequate liquidity, "Some entities are more sensitive than others to negative changes in economic conditions, which can lead to the risk of a going concern issue. In particular, companies that have significant concentrations in major customers and suppliers are at the greatest risk...."
} 
2001). Such strategic alliances can reduce selling and advertising costs (Cowley 1988) and lower inventory and control costs through facilitating better production and inventory management (Ak and Patatoukas 2016; Kalwani and Narayandas 1995; Matsumura and Schloetzer 2018; Patatoukas 2012). These factors can, in turn, strengthen customer-supplier interdependencies and lead to a longer partnership, resulting in a continued revenue stream for the supplier (Fee et al. 2006).

Major customers can also provide an added layer of monitoring aimed at reducing risks in the supply-chain relationship, which can enhance the operational effectiveness and efficiencies of their suppliers (Fee et al. 2006) and foster more conservative financial reporting for suppliers (Hui et al. 2012). The presence of major customers can also signal the provision of specialized or customized products, thereby creating barriers of entry for new competitors (Porter 1980). Supplier firms can also exploit and publicize their contributions to the success of major customers by 'showcasing accounts' to attract additional new customers (Jackson 1985; Weitz et al. 1992).

To the extent that external factors beyond the suppliers' control temporarily override such benefits and expose suppliers to financial stress, the presence of embedded ties with major customers can lower the costs of retaining such customers for distressed suppliers (Irvine et al. 2016). Variation in customer risk preferences can also play a role here in making it costlier for distressed suppliers to retain all smaller customers that collectively produce the same sales in total as a major customer. Major customers have strong incentives to mitigate the default risk of suppliers in order to minimize interruptions to their own production processes. This could occur through major customers agreeing to higher prices and committing to long-term relationships with suppliers (Swinney and Netessine 2009), and subsidizing the restructuring of crucial suppliers (White 2005). In addition, Fee et al. (2006) provide evidence that major customers can protect their supply chain through equity investments and forming strategic alliances with a financially 
constrained supplier. Moreover, the supplier vetting process can enhance the reputation of the supplier, leading to lower cost of debt (Cen et al. 2016). In line with this view, some studies show that major customers can positively affect the profitability of their suppliers (Kalwani and Narayandas 1995; Patatoukas 2012). Collectively, the above arguments suggest that when the auditor is faced with evaluating a financially-distressed firm's going concern assumption, the auditor may determine the presence of major customers increases the likelihood of a turnaround and mitigates going concern risks in that distressed firm.

On the other hand, a risk-based perspective suggests that increased reliance on major customers can exacerbate the risk of default, and thus increase the likelihood of distressed suppliers receiving a GCO. First, major customers can possess strong bargaining power over the terms of trade. They typically require products be manufactured to stringent tolerances and unique design specifications, which may force suppliers to invest heavily in relationship-specific assets. Major customers with strong bargaining power can also extract significant price concessions, which can significantly diminish gross margins for suppliers (Schumacher 1991; Snyder 1996). Their strong bargaining position can also result in major customers securing extended payment periods and larger trade credit, which can further heighten cash flow risks for the supplier firm (Gosman and Kohlbeck 2009; Kim and Henderson 2015). Consistent with this line of reasoning, Kim (2017) and Gosman and Kohlbeck (2009) report that sales to major customers are associated with lower supplier gross margins and profitability. Major customers' "squeezing" supplier profits can result in termination of the relationship and propel the supplier into distress. Additionally, it is possible that suppliers' that rely heavily on major customers are near capacity in terms of generating revenues from existing major customers, ${ }^{6}$ and unless such suppliers are able to significantly

\footnotetext{
${ }^{6} \mathrm{Kim}$ and Henderson (2015) show that major customer dependency brings benefits to the supplier but after a certain point, the benefits from major customer dependency diminishes. Consistent with this view, when we regress annual sales growth on our
} 
increase their customer base from new opportunities, a distressed supplier is unlikely to recover from its existing network of major customers.

A case in point consistent with the asymmetric bargaining power held by the major customer, and supporting the empirical findings, is the "Walmart" effect whereby Exide lost Walmart as a customer because it could not withstand the intense pricing pressure from Walmart. The loss of Walmart cost Exide $\$ 160$ million in annual income that put more pressure on Exide's production costs and the imperative to expand its customer base. Exide's repositioning strategy and operational restructuring to generate new sales from existing and new customers were unsuccessful and resulted in Chapter 11 bankruptcy (Exide 2013).

The second channel through which a distressed supplier's going concern risk is heightened is when a major customer intensifies its research and development (R\&D) and opts to "make rather than buy.' This could occur if major customers seek to source a more efficient source of supplies, increase control over the quality and timing of the supplies, or protect proprietary information spillovers. The move to develop products in-house could effectively transform the former customer into a competitor if the former customer decides to market its new product. Along this vein, Fee et al. (2006) and Raman and Shahrur (2008) report that major customers that increase R\&D are more likely to terminate their supplier relationship. A practice anecdote elaborates this effect. In 2000, Brothers Gourmet Coffees Inc., a leading wholesale distributor of gourmet coffee products, went from producing nine million to 300,000 pounds of coffee a year as a result of its largest customer, Procter \& Gamble, deciding to move production in-house. Business commentators saw Proctor \& Gamble's strategic move as a death knell for Brother's operations (Darwin 2000).

largest major customer reliance proxy, a measure capturing relationship length and the interaction of our largest major customer and relationship length variables, we find a negative and significant $(\mathrm{p}<0.01)$ coefficient on the interaction term. This result suggests that the ability of firms to generate more sales from a major customer for a given relationship length decreases with the extent of their reliance on the major customer. 
Finally, a distressed supplier firm's risk is exacerbated if the major customer experiences financial distress itself and defaults or declares bankruptcy (Lian 2017). The economic consequences suffered by suppliers when their major customers are financially distressed or declare bankruptcy are commonly publicly announced and relatively clear. For example, more than 40 suppliers (e.g., Dura Automotive Systems, Lear Corporation, The Dana Corporation) filed Chapter 11 bankruptcy protection and sought financial aid from the U.S. Treasury Department when their major customers, General Motors and Chrysler, declared bankruptcy in 2009. Investors recognize such economic consequences as Hertzel et al. (2008) and Jorion and Zhang (2009) show that suppliers experience negative abnormal returns around the bankruptcy announcement of their major customers. In addition, Dhaliwal et al. (2016) observe that while the cost of equity is generally greater when suppliers rely heavily on major customers, their cost of equity increases further when major customers are at risk of bankruptcy.

Given the contrasting viewpoints above, how auditors consider greater reliance on major customers in their going concern assessments depends on whether auditors evaluate the benefits to exceed or fall short of the risks from such customers. Thus, we examine the relation between distressed firms' greater reliance on major customers and GCOs without a directional prediction.

\section{Moderating effect of supplier financial health and supplier size}

It is likely that the relationship between greater reliance on major customers and GCOs is influenced by supplier conditions that increase or reduce the risk of reliance on major customers. Prior research suggests that financial health and firm size are two factors that can assist suppliers avert risks that typically stem from greater reliance on major customers (Camuffo et al. 2007).

In relation to financial health, the exposure of already distressed suppliers to even higher financial distress could reflect major customers exploiting their bargaining position to squeeze 
suppliers' profit margins (Lanier et al. 2010). Consistent with this view, we find that our measures of greater reliance on major customers are negatively and significantly $(\mathrm{p}<0.01)$ correlated with the gross margins of suppliers (correlation coefficients range between -0.14 and -0.16 ). While distressed suppliers may request advanced payments from major customers, this can come at the expense of further price concessions. This can place suppliers under more financial pressure and lead to suppliers' own creditors not extending trade credit and concessions, which can threaten the suppliers' ability to meet major customer needs. This can cause major customers to switch to more financially-sound suppliers that can offer the security of high-quality products and other long-term product support. However, given that we cannot discount the possibility of major customers providing greater support to more distressed suppliers to reduce interruptions to their own production, we examine how the relationship between greater reliance on major customers and GCOs varies for suppliers facing higher financial distress without a directional prediction.

With respect to firm size, larger suppliers are likely to have better capabilities to implement total quality management systems (Germain and Spears 1999; Powell 1995; Shah and Ward 2003) and pursue innovation (Shefer and Frenkel 2005; Wagner and Hansen 2005), which should promote the delivery of high-quality products. These firms also have stronger reputations, information environments, networks (Atiase 1985; Diamond and Verrecchia 1991; Lang and Lundholm 1993) and governance (Boone et al. 2007; Ge et al. 2016; Laing and Weir 1999), which can allow them to attract financial support from their major customers and access funds from other external sources (Short and Keasey 1999). These strengths should allow larger suppliers to better prevent and weather the loss of a major customer, thus lowering their exposure to business risks. Consequently, the likelihood of suppliers that rely more heavily on major customers receiving GCOs is expected to be lower for larger suppliers. 


\section{Moderating effect of interrelationships between supplier and major customer}

We also consider how the relationship between greater reliance on major customers and GCOs is affected by more specific supply chain attributes. We commence by considering the relative size of distressed suppliers to major customers. Galbraith's (1952) theory of countervailing power suggests that customers that are relatively larger than their suppliers can exercise greater bargaining power that compels smaller suppliers to conform to their needs and hold prices near costs. This viewpoint also forms a core assumption of strategy scholars such as Porter (1980, p. 24), and has been verified in analytical and empirical studies (e.g., Iozzi and Valletti 2014; Raskovich 2003; Snyder 1996). Hui et al. (2012) show that the bargaining advantages of relatively larger customers can result in suppliers adopting more conservative reporting to arguably limit the customers' downside risks. Larger customers are also likely to be less reliant on smaller suppliers, which may reduce the incentives of larger customers to offer assistance to or financially invest in distressed suppliers (Fee et al. 2006). Furthermore, the length of the major customer and supplier relationship tends to be shorter when the supplier is a small firm (Fee et al. 2006; Bauer et al. 2018). Some studies suggest that suppliers could alleviate the risk of hold-up problems arising from greater reliance on powerful major customers through investing more heavily in product or process innovations that may attract new customers (Inderst and Wey 2007). However, such investments are likely to be more onerous undertakings for financially distressed suppliers and it would be costly to adapt major customer-specific technologies to generate revenues from new customers. Further, the benefits of such innovations may not be realized by suppliers in the shortrun relevant to the going concern assessment. As such, we expect that the supplier firm is more likely to receive a GCO when the major customer is relatively larger than the supplier firm.

We next analyze how the length of the relationship between the distressed supplier and its 
largest named major customer is related to GCOs. Prior studies suggest that long-term business relationships with major customers can generate greater levels of trust, mutual commitment, and information and logistics integration (Bauer et al. 2018; Dion et al. 1995; Prajogo and Olhager 2012), resulting in greater supplier profitability (Reinartz and Kumar 2000). The significant investments in technology and human capital that suppliers may undertake to meet major customers' product and service specifications can also serve as a barrier to entry for new market competitors. These arguments suggest lower exposure of suppliers to going concern risks when they have a longer relationship with their major customer.

However, the extant literature on relationship marketing suggests that the association between longer customer relationships and supplier profitability is somewhat ambiguous given that suppliers may have to offer lower prices to retain such customers. Further, greater reliance on a particular major customer over a longer period may reflect other risks such as the supplier's production systems being tailored for the major customer, which could result in the supplier's inability to generate sales growth from other customers in order to establish a more diversified customer base (Lanier et al. 2010). Consequently, such supplier firms' production technologies may not be sufficiently flexible to rapidly respond to and alleviate the loss of major customers. As such, poor management of major customer relationships can lead to lower profitability in the long run (Grönroos, 2007; Zeithaml et al. 2006), a possibility that is particularly salient to our setting that focuses on financially distressed supplier firms. Therefore, it is not clear how the duration of the relationship between major customers and distressed suppliers will be related to GCOs.

Finally, we consider the effect of the major customer and distressed supplier firm employing the same audit firm because auditors' access to private supply chain knowledge can enhance the auditor's knowledge of risks in the contractual terms and conditions between suppliers 
and major customers (Johnstone et al. 2014). The knowledge of the major customers' financial and strategic plans can also provide the supply chain auditor with access to more private information on factors that can cause suppliers to lose their major customer. Further, prior studies show that auditors are more likely to issue a GCO when facing high litigation risk (Blay 2005; Kaplan and Williams 2013). To the extent that supply chain auditors perceive higher exposure to litigation risk when they are privy to private information on business risks arising from major customers, these auditors may exercise conservative judgment and issue a GCO to suppliers that rely more heavily on major customers. However, it is also possible that that the internal knowledge possessed by supply chain auditors facilitates more informed risk assessments (Johnstone et al. 2014). To the extent that the knowledge of the commonalities shared by supply chain partners allows auditors to better identify mitigating factors for going concern risks, these auditors may perceive lower going concern risks stemming from increased reliance on major customers. As such, we consider how supply chain auditors affect the relationship between greater reliance on major customers and GCOs without a directional prediction.

\section{Research Design}

\section{Sample selection}

Table 1 summarizes our sample selection. The sample begins with 35,753 annual firm-year observations for the years 2002 through 2010 in the Compustat Segments database where major customers and operating segments are identified. ${ }^{7}$ We delete 17,563 observations where two or more customers are identified within an operating segment as it is impossible to know the

\footnotetext{
${ }^{7}$ Our sample period begins in 2002 because data on auditor office locations, taken from Audit Analytics, is necessary for some of our test variables and these data are not available prior to 2000. Further, some control variables require lagged data for up to two years. We end our sample in 2010 due to extensive hand collection of data (e.g., manual matching of disclosed customer names to names identifies in Compustat files).
} 
percentage of sales derived from each individual customer within these segments. ${ }^{8}$ We also delete 3,280 observations with only a government major customer. Since the Compustat Segments file contains data on some firms that voluntarily report the existence of a customer that comprises less than 10 percent of sales, we delete 1,904 observations and perform our analyses only on firms that are required to provide major customer data. ${ }^{9}$ An additional 6,050 observations are deleted due to missing data on other firm-level control variables after merging with the Compustat Annual and Audit Analytics databases. Finally, we follow prior studies and delete 3,815 observations of nondistressed firms. Hopwood et al. (1994) show that an analysis of GCOs is only pertinent for distressed firms. ${ }^{10}$ We define distressed firms similar to prior literature as those that exhibit negative net income, negative cash flows, or both, in fiscal year t (Blay and Geiger 2013; DeFond et al. 2002; Reynolds and Francis 2001). ${ }^{11}$ Our 'Final Full Sample' consists of 3,141 observations from 1,251 unique firms and multivariate tests using this sample are reported in Tables 3 and 4.

\section{[Insert Table 1 Here]}

Our tests based on specific attributes of the relationship between the distressed supplier and its largest major customer (i.e., relative size, relationship length, and same audit firm) require firm data and the identity of the auditor for these major customers. Extensive procedures were

\footnotetext{
${ }^{8}$ The specific customer name is often not disclosed in the Compustat Segments file. However, there is usually information that identifies the type of customer or segment (e.g., "one company" or "multiple companies" or domestic, local or foreign "government," etc.). We retain only observations where a single company (specifically identified by name or not) is identified as the reporting segment when calculating our test variables of interest, as described later in more detail.

${ }^{9}$ We drop these observations because retaining all firms (i.e., including firms that do not have a large customer, whether or not it is voluntarily reported) and comparing whether the presence of a large customer affects GCOs is not appropriate methodologically. This comparison would effectively compare all supplier firms with customers that make up more than 10 percent of sales to all supplier firms with customers that comprise less than 10 percent, using a dichotomous indicator variable. The problem with this analysis is that a firm with a customer that comprises, for example, one percent of sales would be treated exactly the same as a firm with a customer that makes up nine percent of sales, and treats a firm with a customer comprising 11 percent of sales the same as a firm with a customer that makes up 70 percent of sales. Further, it would treat the nine percent firm differently from the 11 percent firm. Due to this issue, we retain only firms with large customers (greater than 10 percent) and compare within this group of firms using continuous measures of the importance of the large customers (detailed in the next section).

${ }^{10}$ As such, we believe that there is no need to implement a selection model to generalize our findings to distressed firms because our conclusions would apply to the going concern assessments for distressed firms only. However, we note that all results are virtually identical if we retain these non-distressed firms in our sample.

${ }^{11}$ Our inferences are unaffected when we restrict our analyses to distressed firm-year observations with both negative income and negative cash flows in the same year $(n=1,110)$ or to those with negative income in the current and prior periods $(n=531)$.
} 
employed to match customers from the Compustat Segments file with firm-level Compustat data necessary to execute these tests. First, we employ the exact procedure as Fee and Thomas (2004, pg. 436-437) and Dhaliwal et al. (2016, pg. 33) to match the major customer names identified in the Segments file to names identified in the Compustat Fundamental Annual file. For major customers we could not match using this procedure, we performed manual matches (by identifying the company name and its GVKEY in the Annual file). A total of 1,746 observations are deleted where the major customer name cannot be identified or without data to measure the attributes of the relationship between the supplier and its largest major customer. This leaves us with 1,395 observations from 678 supplier firms for these multivariate analyses that are reported in Table 5. We refer to this as our 'Final Reduced Sample. ${ }^{12}$

\section{Empirical model}

We estimate the following logistic regression model to test whether greater reliance on a major customer(s) is associated with a GCO:

Prob. $($ Going Concern Opinion $)=$ function $($ Extent of reliance on major customers, Auditor Controls, Company Controls, Year and Industry Fixed Effects)

where the dependent variable, GOING_CONCERN, equals one if the firm's auditor issues a GCO in fiscal year $\mathrm{t}$, and zero otherwise. All variables are defined in the Appendix.

We compile data used to measure our main test variables using the Compustat Segments database. This database provides sales amounts and identities of segments/customers as they are

\footnotetext{
12 Our Final Reduced Sample of about 155 observations per year initially appears smaller than the sample size employed in prior major customer studies. For example, Patatoukas (2012) employs a sample size of around 538 identified major customer observations per year to examine the relationship between reliance on major customers and firm performance. Our comparatively lower sample size is largely driven by two factors: (1) the requirement of restricting our sample to financially distressed firms as per prior going concern studies, and (2) controlling for a large number of control variables to reduce potential omitted variables bias. The inclusion of non-financially distressed firms and the exclusion of our auditor-related and other controls not employed by Patatoukas (2012) results in a sample of around 869 observations per year, which compares favorably to the sample size used by Patatoukas (2012) and other major customer studies such as Raman and Shahrur (2008) and Fee et al. (2006).
} 
disclosed in firms' SEC filings. Our main test variable, CUST_MEASURE, represents one of three measures of the extent of reliance on major customers. The first measure, MAJ_CUST_SALES_\%, is the percentage of sales contributed by the firm's largest major customer. Our second measure, TOT_CUST_SALES_\%, is the percentage of sales contributed by all customers that comprise at least 10 percent of a firm's sales in year t. Finally, our third measure, HERF_CUST_SALES, is a Herfindahl index calculated across all customers that contribute at least 10 percent of a firm's sales in year t. A higher value of this variable indicates that sales is more concentrated in one or a few major customers rather than relatively evenly spread amongst all major customers. Consequently, all three customer measures are larger as supplier reliance on major customers increases.

We also include a large set of control variables. First, we control for the severity of supplier firms' distress using the Zmijewski (1984) bankruptcy score (SUPP_BK_SCORE) and expect a positive coefficient on this variable (Lian 2017). Next, we control for audit market competition using the spatial competitive distance measure, DISTANCE, employed in Numan and Willekens (2012). We also include a BIG_4 indicator, the proportion of non-audit fees to total fees paid by firms to their external auditor (FEE_RATIO), natural log of the number of clients audited by an auditor office (LnOFFICE_SIZE), and an indicator for city-level auditor industry specialization (IND_EXPERT). We make no prediction on these auditor variables due to conflicting results in the going concern literature (Carson et al. 2013; DeFond et al. 2002; Francis and Michas 2013; Frankel et al. 2002; Lawrence et al. 2011; Minutti-Meza 2013). Finally, we control for many other variables used in prior studies (SIZE, ABS_AB_ACC, FIRM_AGE, BETA, RETURN, VOLATILITY, LEVERAGE, PRIOR_YR_LOSS, INVESTMENTS, DEBT_ISSUE, EQUITY_ISSUE CFO, 
NUM_OP_SEGS, and LAG_GOING_CONCERN). ${ }^{13,14}$

As discussed earlier, we also assess how the effect of our major customer reliance measures on GCOs varies based on high and low levels of supplier financial distress (SUPP_BK_SCORE), supplier size (SIZE), the relative size of a supplier to its largest major customer (REL_SIZE), the length of the relationship with its largest major customer (REL_LENGTH), and whether the supplier and its largest major customer employ the same audit firm (REL_AUD). We measure REL_SIZE as the total sales of the supplier to its largest major customer scaled by that major customer's cost of goods sold, and REL_LENGTH as the length of a supplier's relationship (in years) with their largest major customer. REL_AUD is coded 1 of a supplier and their largest major customer use the same audit firm in a year, and 0 if they use different audit firms.

\section{Results}

\section{Descriptive statistics and univariate tests}

Table 2, panel A (panel B) presents descriptive statistics for our Full (Reduced) sample of distressed supplier firms. The Full Sample is used for our baseline tests (Table 3) as well as tests that investigate specific supplier characteristics (Table 4). The Reduced Sample is used for tests that investigate specific major customer characteristics in relation to the supplier (Table 5) because specific data requirements for these characteristics are not available for all major customers. Values of variables are similar across the two samples so we discuss only the Full sample here.

\footnotetext{
${ }^{13}$ We expect SIZE, RETURN, LEVERAGE, INVESTMENTS, DEBT_ISSUE, EQUITY_ISSUE and CFO to be negatively related to GCOs, while we expect ABS_AB_ACC, BETA, VOLATILITY and PRIOR_YR_LOSS to be positively associated with GCOs (e.g., Behn et al. 2001; Blay and Geiger 2013; DeFond et al. 2002; Reynolds and Francis 2001). We do not predict a sign for FIRM AGE or our variable that proxies for firm operational diversity (NUM_OP_SEGS). Importantly, we include whether a GCO was issued for a firm in year t-1 (LAG_GOING_CONCERN) and expect this variable to be positively associated with current year GCOs.

${ }^{14} \mathrm{We}$ include year and industry fixed effects (based on 1-digit SIC codes) to control for differing levels of GCOs within years and industries due to both macro-economic effects and difference in auditor reporting conservatism across time and industry. Our results are qualitatively similar when we omit either year or industry fixed effects (or both), or when we include industry fixed effects based on 2-digit SIC codes. Standard errors in all regression models are clustered at the firm level. Two-tailed z-statistics and pvalues are reported throughout the study.
} 
The mean value of GOING_CONCERN indicates that 7.6 percent of our sample of supplier firms receive a GCO, which is similar to other studies (e.g., DeFond et al. 2002). The mean (median) value of MAJ_CUST_SALES_\% is 0.306 (0.229), which indicates that a firm's largest major customer provides roughly 30 percent of total sales on average. The corresponding value of 0.422 (0.360) for TOT_CUST_SALES_\% is expectedly higher as this measure considers all major customers, not just the largest. Finally, the mean and median values for HERF_CUST_SALES are 0.158 and 0.074 , respectively. The mean (median) value for SUPP_BK_SCORE is -1.993 (2.635). ${ }^{15}$ The mean (median) value of REL_SIZE (in panel B) equals $0.029(0.003)$, indicating that sales to the major customer makes up a relatively small percent of that major customer's cost of goods sold. ${ }^{16}$ The mean value of REL_LENGTH indicates that the average length of the relationship between suppliers and their largest major customer is around 2.9 years, while the mean value of REL_AUD indicates that around 21 percent of suppliers employ the same audit firm as their largest major customer. Summary statistics on all other variables are similar to prior research. [Insert Table 2 Here]

Table 2, panel C, shows that the mean and median values of our major customer measures are significantly greater for firms that receive a GCO compared to those that do not in both the Full and Reduced samples. These results support the view that auditors' going concern status

\footnotetext{
${ }^{15}$ When we compute the major customer bankruptcy scores (financial distress level) of firms' largest customer (MC_BK_SCORE) in the same manner as that for the supplier (SUPP_BK_SCORE), we find that the mean (median) value for MC_BK_SCORE (shown only in panel B) is $-3.022(-3.583)$. When compared to the corresponding values for SUPP_BK_SCORE, these statistics suggest that suppliers are generally more distressed than their largest customer in our sample. We also find that SUPP_BK_SCORE is significantly $(\mathrm{p}<0.01)$ and positively correlated with $M C \_B K \_S C O R E$ (correlation coefficient $\left.=0.24\right)$ suggesting that the risk from distressed dominant major customers is a significant component of the exposure of suppliers to financial distress. In order to assess whether the level of customer distress that is correlated with supplier distress may be impacting our results, we orthogonalize SUPP_BK_SCORE with respect to MC_BK_SCORE and find that our conclusions for SUPP_BK_SCORE are unaffected when we use these orthogonalized values in our analysis. Nonetheless, as part of our additional tests, we assess the effect of the distress levels of major customers on the relationship between the effect of greater reliance on major customers and GCOs as our results based on SUPP_BK_SCORE could be reflective of major customer distress.

${ }^{16}$ Untabulated Pearson and Spearman correlations show the vast majority of correlations among the independent variables are below 0.20 . Further, the largest correlation between any of our test and control variables is 0.352 , and the vast majority are below 0.15 , indicating that multicollinearity is not likely to be of concern. This conclusion is supported by variance inflation factors in the model estimations which are all less than 2.0, well below the threshold of 10.0 suggested in Kennedy (1992).
} 
assessments are negatively affected by the extent of firms' reliance on major customers for sales.

\section{Multivariate tests - greater reliance on major customers and going concern opinion}

Table 3 presents our baseline logistic regression results. The results presented in the three columns reveal positive and significant $(\mathrm{p}<0.05$ and $\mathrm{p}<0.10)$ coefficients on our three major customer test variables. These indicate that auditors are more likely to issue a GCO to distressed firms that generate a higher percentage of sales from major customers (MAJ_CUST_SALES_\% and TOT_CUST_SALES_\%), and to firms where sales to major customers are more concentrated among fewer of these customers (HERF_CUST_SALES). These results suggest that auditors perceive higher going concern risks arising from greater reliance on major customers.

[Insert Table 3 Here]

The results are also economically important and show that a firm is 22.7 percent more likely to receive a GCO when our test variable MAJ_CUST_SALES_\% moves from one standard deviation below to above its mean value. ${ }^{17}$ These results are a 29.1 and 22.1 percent increase for our test variables TOT_CUST_SALES_\% and HERF_CUST_SALES_\%, respectively. Finally, pseudo R-square magnitudes for our models are about 40 percent, the area under the ROC curves are greater than 90 percent (indicating a highly predictive model), and the coefficients on control variables are mostly in the predicted direction and often significant.

\section{Multivariate tests - moderating effect of supplier financial distress and size}

As discussed earlier, we conjecture that the relationship between greater reliance on major

\footnotetext{
${ }^{17}$ Because the coefficients in a logistic model are not directly interpretable in terms of importance, we calculate this using the 'margins' command in STATA which allows us to calculate the marginal effect of our test variable. First, we standardize the test variable so that it has a mean of zero and standard deviation of 1.0. Next, using the 'margins' command in STATA we calculate the marginal impact of the test variable while holding all other variables at their mean values. The marginal impact equals 0.00784 , which represents a 0.784 percent increase (decrease) in the probability a firm will receive a GCO as the value of MAJ_CUST_SALES_\% increases (decreases) by one unit (i.e. 1.0). We then calculate the percentage change from going from one standard deviation below (or one unit given the variable is standardized) to one standard deviation above (again, one unit above) the mean value, which equals $(.0764+.00784) /(.0764-.00784)=1.227$ or a 22.7 percent increase. The one standard deviation below (above) the mean value of MAJ_CUST_SALES_\% is 10.24 (51.50) percent.
} 
customers and GCOs is likely to be moderated by the supplier's financial health and size. We examine this by estimating separate models on subsamples representing firms with lower versus particularly high supplier financial risk and small/large supplier size. ${ }^{18}$

The results reported in Table 4, panel A indicate that our major customer measures are not significantly associated with GCOs in our sample of relatively healthy supplier firms (below median value of SUPP_BK_SCORE) in columns (1) through (3). ${ }^{19}$ Conversely, we find a positive and significant $(\mathrm{p}<0.05)$ association using all three test measures in our relatively financially unhealthy sample (above median value of SUPP_BK_SCORE) in columns (4) through (6). Coefficient comparisons across the models in the two samples indicate that the coefficient TOT_CUST_SALES_\% is significantly different (and MAJ_CUST_SALES_\% is only marginally insignificantly different with a p-value equal to 0.129 ). This suggests that auditors consider greater reliance on major customers in their going concern assessments only when distressed suppliers are relatively closer to bankruptcy. Economic significance analyses show that financially unhealthy firms are between 28.4 and 39.5 percent more likely to receive a GCO as our three major customer reliance measures shift from one standard deviation below to one above their mean values.

[Insert Table 4 Here]

Table 4, panel B presents sub-sample regressions for relatively small compared to large distressed supplier firms (split based on the median value of supplier total assets [SIZE] in this

\footnotetext{
${ }^{18}$ We use this approach rather than using an interaction-based model because Norton, Wang, and Ai (2004) suggest that interaction effects in logistic models may not correctly reflect the marginal effect. Instead, we formally test whether the coefficients on our test variables across the two models are different. Specifically, we run a Chi-Square test of coefficient differences using the postestimation 'test' command in STATA and cluster standard errors at the firm level to test for differences in coefficients of our test variables across models. We also note that this research design choice lowers the power of our tests overall, leading to a lower possibility of finding significant results. However, our conclusions are unaffected if we use models that include interaction terms (untabulated).

${ }^{19}$ We create our 'high' and 'low' supplier BK score sub-samples by splitting at the median value of SUPP_BK_SCORE before reducing the number of observations due to missing major customer concentration data. Thus, this represents the 'median' level of supplier financial distress for a more general sample of firms. If we split this after the sample reduction we find our results are virtually identical.
} 
subsample). We find that our major customer reliance measures are positively and significantly $(\mathrm{p}<0.05)$ associated with GCOs for larger supplier firms. Interestingly, the corresponding coefficients are positive but insignificant, albeit marginally ( $\mathrm{p}$-values are about 0.13 for all), for smaller supplier firms. However, the coefficients across models are never significantly different. Taken together, this suggests that the effect of greater reliance on major customers on GCOs is unaffected by the size of suppliers. ${ }^{20}$ Economically, relatively small (large) firms are between 16.8 and 21.3 (74.7 and 78.2) percent more likely to receive a GCO as our major customer reliance measures shift from one standard deviation below to one above their mean values. It is possible this relationship is affected by the relative size of suppliers and major customers. We consider this next in our tests based on the characteristics of the supplier-major customer relationship.

\section{Multivariate results - moderating effect of supplier-major customer relationship characteristics}

We next consider how our results are affected by the relative size of the largest major customer to the distressed supplier, the length of the relationship between a distressed supplier and its largest major customer, and whether the distressed supplier and largest major customer utilize the same audit firm. In these analyses, we only present the MAJ_CUST_SALES_\% test variable, which represents reliance on the firm's largest major customer. ${ }^{21}$

Table 5, panel A analyzes the effect of the relative size of the supplier and its largest major customer, which may reflect the bargaining power of larger major customers that can expose

\footnotetext{
${ }^{20}$ Our conclusions on the differences between small and large suppliers are unaffected when we split the firms into small and large subsamples within the more distressed group of suppliers from panel A $(n=1,482)$. Specifically, these analyses reveal positive and significant $(\mathrm{p}<0.05)$ coefficients on our test variables for both small and larger supplier firms, with no significant differences in the coefficients across the two subsamples. Economic significance is also very similar across the two size groups when considering only financially distressed suppliers.

${ }^{21}$ We do this because these supplier-major customer relationship characteristics would need to be averaged over all major customers for the other two test variables, which would mitigate the impact of the supplier's most important customer. Further, calculating the average of these characteristics over all major customers would significantly distort relationship length measures, and is not possible to do when considering whether the supplier and major customer use the same auditor. However, if we apply our other two major customer reliance measures to our relative size analysis in panel A after taking into account sales made to all major customers scaled by the average of those customers' COGS, our results are virtually identical.
} 
suppliers to higher hold-up costs and other business risks. As discussed earlier, we measure relative size (REL_SIZE) by scaling the total sales made by the supplier to its largest major customer by that customer's cost of goods sold. Therefore, smaller values of REL_SIZE indicate larger bargaining power in that the major customer is not overly reliant on the supplier for its total purchases, and can thus switch to a different supplier rather easily if the supplier does not comply.

[Insert Table 5 Here]

In line with this view, we find that MAJ_CUST_SALES_\% is positively and significantly associated with GCOs only in column (2) which utilizes the high major customer bargaining power sub-sample (REL_SIZE less than or equal to the median value). The coefficient on MAJ_CUST_SALES_\% in column (1) based on the sub-sample with low major customer bargaining power is not significant (and the coefficients across columns [1] and [2] are significantly different). ${ }^{22}$ The firms in column (2) are 75.2 percent more likely to receive a GCO as MAJ_CUST_SALES_\% shifts from one standard deviation below to one above its mean value.

Table 5, panel B considers the effect of the length of the relationship between the supplier and its largest named major customer (REL_LENGTH) after repeating our main analyses across two sub-samples representing short relationships (REL_LENGTH less than or equal to three years, the median value) and long relationships (REL_LENGTH four or more years) ${ }^{23} \mathrm{We}$ find that our major customer reliance measures are positively (negatively) associated with GCOs for suppliers that exhibit a relatively short (long) relationship with their major customers (at the $\mathrm{p}<0.10$ level or smaller, two-tailed). The difference in the coefficients on MAJ_CUST_SALES_\% between the two models is significant $(\mathrm{p}<0.05)$. These results are consistent with auditors viewing suppliers as

\footnotetext{
${ }^{22}$ This analysis is robust to measuring the relative size split based on the median value of the ratio of the largest major customer's total assets to the total assets of the supplier firm.

${ }^{23}$ In untabulated analyses, we also include the raw version of relationship length (i.e. one, five, ten years, etc.) in all of our models. Results including this additional control variable are virtually identical for all tabulated analyses.
} 
being more susceptible to going concern risks when they engage in shorter relationships with large customers. Economically, firms with a relatively short (long) relationship with their largest major customer in column 1 (column 2) are 43.3 (37.7) percent more (less) likely to receive a GCO as MAJ_CUST_SALES_\% shifts from one standard deviation below to one above its mean value.

The analyses in panel $\mathrm{C}$ of Table 5 consider how our main findings are affected by the supplier and major customer employing the same audit firm $\left(R E L \_A U D=1\right)$ or different audit firms $\left(R E L \_A U D=0\right)$. The results indicate that greater reliance on major customers is negatively (positively) associated with GCOs when the supplier and largest major customer use the same (a different) audit firm. The difference in the coefficient on MAJ_CUST_SALES_\% between the two models is significant $(p<0.01)$. The results suggest that the information advantages of supply chain auditors allow them to better identify mitigating factors in the going concern context. However, we interpret this result with caution given that the subsample of suppliers and major customers with the same audit firm is very small $(\mathrm{n}=295)$. Greater reliance on major customers remains positively associated with GCOs for supplier firms that employ a different audit firm. Economic significance analyses show that firms who share (do not share) an auditor with their largest major customer are 56.4 (32.4) percent less (more) likely to receive a GCO as MAJ_CUST_SALES_\% shifts from one standard deviation below to one above its mean value. Again, we interpret these results with caution.

\section{Additional tests}

\section{Propensity score matching}

We next perform our baseline analyses in Table 3 using a propensity matched (PSM) sample to assemble control firms that exhibit covariate balance (Shipman et al. 2017). We identify the PSM sample for our main analyses in columns (1) through (3) after matching distressed 
supplier firms with a relatively 'high' level of reliance on major customers with a sample of distressed firms with a relatively 'low' reliance based on the median value of MAJ_CUST_SALES_\%. ${ }^{24}$ This PSM procedure creates two sub-samples of supplier firms that achieve covariate balance on all control characteristics based on the extent to which they rely on major customers. ${ }^{25}$ Therefore, our PSM sample contains firms that are relatively similar to each other except for their above-median versus below-median level of reliance on major customers. ${ }^{26}$ This model achieves strong covariate balance where only one variable, LEVERAGE, is significantly different between the matched samples $(p=0.083)$. We then estimate the same models as in Table 3 for all columns and find qualitatively similar results. We note this is the case even though PSM can weaken statistical significance because it results in smaller sample sizes. ${ }^{27}$

To address the sample size issue of the PSM method, we also repeat our analysis using an entropy balancing approach. This allows us to retain our original sample size using an algorithm to reweight the covariates in a manner that leads to no significant post-weighting differences in the mean, variance, and skewness of these covariates (Hainmueller 2012; Hainmueller and Xu

\footnotetext{
24 In our PSM model, the dependent variable is HIGH_MAJ_CUST_SALES_\% which equals 1 when the value of MAJ_CUST_SALES_\% is above the median value for all supplier firms, and 0 when below. We regress this on our complete set of control variables without replacement and with a caliper distance of 0.01 .

${ }^{25}$ It is interesting to note the differences that exist between supplier firms with relatively low compared to high reliance on major customers before we implement our matching procedures. Firms with high major customer reliance exhibit significantly larger (smaller) auditor office size, bankruptcy score, abnormal accruals, prior year losses, investments, and equity issuances (fee ratio, total assets, firm age, stock returns and return volatility, cash flows from operations, and number of operating segments) compared to firms with low major customer reliance.

${ }^{26}$ We note that Shipman et al. (2017) conclude that altering a continuous variable into dichotomous form for the purposes of creating a propensity-matched sample can be problematic because it diminishes the power of tests, increasing the likelihood of a false negative. Further, we note that our PSM samples exhibit significant differences in our major customer measures. For example, the mean (median) value of MAJ_CUST_SALES_\% for firms in the low major customer reliance sample is 0.159 (0.158) while these values are $0.353(0.405)$ for firms in the high reliance sample. These are in comparison to the overall values of 0.229 (.300) when considering both samples together. This mitigates the concern that our matched firms are simply very close together in terms of their level of reliance on major customers in that neither sub-sample is near the overall mean and median value. Therefore, the matched samples are very similar on other characteristics, but not similar on their extent of reliance on major customers.

27 We also attempted to further address any endogeneity concerns in our sample using an instrumental variables approach. Specifically, we follow Campello and Gao (2017) and consider merger and acquisition activity in customers' industries (downstream M\&A) as an instrument based on the assumption that suppliers depict a more concentrated customer base after conducting M\&A in their customers' industries. However, results from Wald tests fail to reject the null hypothesis of exogeneity in our setting, suggesting that our analysis is not exposed to an endogeneity problem. We arrive at a similar conclusion when we follow Cen et al. (2017) and consider the percentage of principal customer firms in a supplier's industry or the durable goods industry as potential instrumental variables.
} 
2013). The results from this extension indicate that our three measures of major customer concentration remain positively and significantly related to GCOs.

\section{First-time going concern opinions}

Next, we re-estimate our Table 3 analyses on a sample of distressed firms only with firsttime GCOs. Therefore, we delete all observations in year $\mathrm{t}$ that received a GCO in year $\mathrm{t}-1$ as well. We find our results are very similar, albeit statistical significance is a bit weaker. We note this could be due to a reduction in sample size for this analysis. Further, we note that we control for lagged GCOs in all our tabulated analyses, thus mitigating the effect of possible autocorrelation due to firms that receive GCOs in consecutive years.

\section{Presence and loss of a major customer}

Our main analyses drop observations that do not have a major customer because comparing whether the presence of a large customer affects going concern assessments would effectively treat all supplier firms with customers that make up more (less) than 10 percent of sales in the same manner. Indeed, when we execute our analyses based on an extended sample $(n=10,198)$ that consists of 3,141 observations with a major customer (i.e., our Final Full sample) and 7,057 observations without a major customer but with available data for all other variables included in our regression analysis, we find that the mere presence of a major customer (i.e., a non-missing value of our major customer variables) is not a driver of whether a firm receives a GCO.

A more interesting analysis is to consider how GCOs are affected by the loss of major customers. Such an analysis can provide useful insights relating to a change in sales strategy and is more directly related to our arguments on how the risk of losing major customers can cause going concern problems in distressed suppliers. However, such an analysis is also exposed to a data issue in that if a disclosed major customer in year $t-1$ contributed less than 10 percent of sales 
in year $t$, the supplier is not required to disclose this important customer in year $t$, which would result in falsely concluding that the supplier had lost this important customer in year $t$. We attempt to ameliorate this issue by identifying major customer losses in year $t$ as cases where suppliers disclose a specific major customer in both years $t-2$ and $t-1$ but did not disclose that customer in years $t$ and $t+1$. We then assess whether auditors are more likely to issue a GCO in year $t$ to firms that lose a major customer relative to a set of control firms that possess a major customer in years $t-1$ and $t$. While this analysis returns an insignificant result for major customer losses, the test suffers from reduced power due the small number of major customer losses identified $(\mathrm{n}=342)$.

However, it is possible that the effect of the loss of a major customer can be contingent on how dependent the distressed supplier is on that lost major customer. Consistent with this view, we find that the loss of a major customer is positively associated $(\mathrm{p}<0.10)$ with a GCO when (1) the lost customer was the supplier's only major customer compared to the lost customer being one of the supplier's multiple major customers, and (2) when the lost major customer contributed more sales [more than 50 percent] compared to when the lost major customer contributed less sales. These results are consistent with our theoretical arguments on the potential loss of a major customer heightening going concern risks. However, we interpret these results with caution given the difficulty of identifying losses of major customers due to the mandatory disclosure threshold.

\section{Instances where major customers rely on suppliers for purchases}

We also 'transpose' our dataset to consider the likelihood of distressed major customers receiving GCOs when they rely more heavily on their suppliers (proxied by the value of purchases from suppliers divided by cost of sales). Our results from these tests reveal a negative and significant $(\mathrm{p}=0.039)$ relationship between greater supplier reliance and GCOs in major customers with higher financial distress levels (i.e., above median value of MC_BK_SCORE, which captures 
major customer bankruptcy scores measured in the same manner as that for the supplier). This suggests that auditors perceive distressed firms to benefit from lower going concern risks when they rely heavily on major suppliers. This could reflect the overall bargaining power a major customer possesses relative to its suppliers as we discuss throughout the study. Given the small sample used in this test as a result of transposing our dataset, this initial evidence presents an avenue for future studies to further examine the going concern risks stemming from increased reliance on suppliers.

\section{Other analyses}

We conduct a wide range of other tests. First, we find that our results are unaffected when we use Ohlson's (1980) bankruptcy O-score in place of the Zmijewski (1984) bankruptcy score to identify healthy and unhealthy firms. Second, we extend our baseline analysis in Table 3 to examine how GCOs are affected by government major customers that are less likely to go bankrupt and, thus, represent a stable source of demand and creditworthiness (Banerjee et al. 2008). Further, in contrast to non-government customers that procure goods for production or resale, the government generally purchases goods for consumption and, thus, is less likely to be concerned with reputational or monetary losses from poor product quality. We find that distressed supplier firms are less likely to receive GCOs when there is greater reliance on government major customers. These results support the view that auditors perceive lower business risks associated with greater reliance on government customers.

Third, we test whether the largest major customer's bankruptcy score moderates our main results. We perform this test similar to our Table 4, panel A analysis for supplier financial distress, except that we use the median value of the year $\mathrm{t}$ level as well as the year $\mathrm{t}-1$ to year $\mathrm{t}$ change in distress score of the firm's largest major customer (MC_BK_SCORE) to arrive at two sub-samples 
representing particularly high and low customer financial distress. We find that the positive relationship between greater reliance on major customers and GCOs holds only for our high level and high change in customer financial distress score sub-samples.

Finally, to ensure that our results are robust to non-financial crisis years, we create an indicator variable equal to one for the years 2008 and 2009. We then interact this with our major customer measures. We find that the main effect on the customer measures is virtually identical to our main results indicating that the association exists in non-financial crisis years. Further, the interaction between this indicator and our major customer reliance measures is never significant ( $>0.20$ in all cases), indicating no incremental impact on the association during the crisis years.

\section{Conclusion}

This study provides evidence of a positive relationship between suppliers' greater reliance on major customers and the propensity of auditors to issue GCOs, which is driven by more financially distressed suppliers. Our results based on more distressed suppliers are consistent with auditors viewing major customers as adversely affecting the suppliers' financial condition and/or a higher risk of discontinued sales from these customers switching to other suppliers. We also find that the positive effect of greater reliance on major customers on GCOs holds only for suppliers that are relatively smaller than their largest major customer, suppliers in shorter relationships with their largest major customer, and suppliers that use a different audit firm than their largest major customer. These results suggest that auditors perceive suppliers to be exposed to higher business risks when their major customers have higher bargaining power or have shorter relationships with suppliers, and when major customers employ a different audit firm. These findings highlight the importance of required disclosures about customer concentration and the auditor's consideration of major customer associated business risks in GCOs. 
Our research is subject to several caveats. First, while we conduct tests to address endogeneity problems our study documents association and not causation. However, the fact that we document results across several subsamples reduces the threat of endogeneity as any unobservable driver of GCOs would have to be correlated with greater reliance on major customers and factors captured in these various partitions (e.g., supplier health, relative size). Second, similar to prior studies utilizing customer disclosures, our study is subject to several limitations that arise from SEC regulations or FASB accounting standards regarding the identity of major customer(s). Since issuers are not required to disclose the identity of their major customers, nor are they required to disclose specific contractual details, we are unable to extensively examine other supplier and major customer characteristics (e.g., presence of long-term contracts between a supplier and its customers; terms and conditions of the contract including prices, discounts, payment schedules, pending contract renegotiations, etc.). While we acknowledge these additional factors may be considered by auditors, we encourage future research to explore potential sources of such factors (e.g., audit work papers, proprietary data) to further our understanding of auditors' GCOs to firms relying on major customers to a greater extent. Such future research can help identify factors (e.g., bargaining power, inability to diversify customer base) that may drive the positive relationship between greater reliance on major customers and GCOs. 


\section{Appendix. Variable definitions}

\section{Variable}

Dependent Variable: GOING_CONCERN

Test Variables:

MAJ_CUST_SALES_\%

TOT_CUST_SALES_\%

HERF_CUST_SALES_\%

Moderating Variables: SUPP_BK_SCORE

REL_SIZE

REL_LENGTH

REL_AUD

MC_BK_SCORE

\section{Control Variables: DISTANCE}

BIG_4

FEE_RATIO

LnOFFICE_SIZE

IND_EXPERT
Definition of variable

$=$ equals 1 if the auditor issues a going concern opinion for the fiscal year, and 0 otherwise.

$=$ the percentage of sales contributed by the firm's largest customer in year $\mathrm{t}$.

$=$ the total percentage of sales contributed by all customers that comprise at least 10 percent of a firm's sales in year $t$.

$=$ the Herfindahl index calculated across all customers that contribute at least 10 percent of a firm's sales in year t. A higher value of this variable indicates that sales to major customers are more concentrated in one or a few of the major customers rather than relatively evenly spread amongst all major customers.

$=$ the probability of bankruptcy score based on the model created by Zmijewski (1984) for the firm in year $t$. A higher value of this score indicates that a firm is in greater distress and is calculated separately for each year.

$=$ total sales of the supplier firm to its largest major customer scaled by that major customer's cost of goods sold.

$=$ length of the relationship (in years) between the supplier firm and its largest major customer.

$=1$ if the supplier and its largest major customer employ the same audit firm, and 0 otherwise.

$=$ the probability of bankruptcy score based on the Zmijewski (1984) model for a firm's largest major customer in year t. A higher value of this score indicates that a firm is in greater financial distress and is calculated separately for each year.

$=$ the spacial competitive distance measure adopted from Degryse and Ongena (2005) and Numan and Willekens (2012). This is measured as the absolute distance between the firm's auditor and the closest competitor auditor, based on industry market share of audit fees, within the same metropolitan statistical area in year $\mathrm{t}$.

$=1$ if the firm's auditor is a Big 4 audit firm in year $\mathrm{t}$, and 0 otherwise.

$=$ the proportion of non-audit fees to total (non-audit and audit) fees paid to the external audit firm in year $t$.

$=$ the natural log of the number of clients audited by an auditor office in year $\mathrm{t}$.

$=$ a measure of city-level auditor industry expertise based on Francis et al. (2005). This variable is coded 1 if the office has the largest dollar amount of audit fees within an industry-year grouping among all auditor offices in the same metropolitan statistical area (MSA) as classified by the U.S. Census Bureau in year $t$, and 0 otherwise.

$=$ the natural $\log$ of total assets in year $\mathrm{t}$. 
ABS_AB_ACC

FIRM_AGE

BETA

RETURN

VOLATILITY

LEVERAGE

PRIOR_YR_LOSS

INVESTMENTS

DEBT_ISSUE

EQUITY_ISSUE

CFO

NUM_OP_SEGS

LAG_GOING_CONCERN
$=$ the absolute value of abnormal accruals, adjusted for performance, in year $\mathrm{t}$ as calculated in Kothari et al. (2005).

$=$ the number of years a firm has been operating as a publicly traded company as of year $t$. The natural $\log$ is used in all regression analyses.

$=$ the firm's beta per the Market Model over year $\mathrm{t}$.

$=$ the firm's stock return during year t.

$=$ variance of the residual from the Market Model for a firm over year $\mathrm{t}$.

$=$ total debt scaled by total assets at the end of year $\mathrm{t}$.

$=1$ if net income in year $\mathrm{t}-1$ is below zero, and 0 otherwise.

$=$ short and long-term investment securities, including cash and cash equivalents, scaled by total assets at the end of year $t$.

$=1$ if new debt is issued during year $\mathrm{t}+1$, and 0 otherwise.

$=1$ if new common equity is issued during year $\mathrm{t}+1$, and 0 otherwise.

$=$ cash flows from operations scaled by total assets in year $\mathrm{t}$.

$=$ number of operating segments for a firm in year $\mathrm{t}$.

$=1$ if the auditor issued a going concern opinion in the prior fiscal year, and 0 otherwise. 


\section{References}

AICPA. 2006. Statement on Auditing Standard (SAS) 59: The Auditor's Consideration of an Entity's Ability to Continue as a Going Concern. American Institute of Certified Public Accountants. Available online at: http://www.aicpa.org/research/standards/auditattest/pages/sas.aspx. Last accessed $\underline{5 / 27 / 2016 .}$.

Ak, B. K., and P. N. Patatoukas. 2016. Customer-base concentration and inventory efficiencies: Evidence from the manufacturing sector. Production and Operations Management Journal 25 (2): 258-72.

Arnold, V., and D. E. Edwards. 1993. Going-concern evaluation: Factors affecting decisions. The CPA Journal 63 (10): 58

Atiase, R. 1985. Predisclosure information, firm capitalization, and security price behavior around earnings announcements. Journal of Accounting Research 23 (1): 21-36.

Audousset-Coulier, S., Jeny, A, and L. Jiang. 2016. The validity of auditor industry specialization measures. Auditing: A Journal of Practice \& Theory 35 (1): 139-61.

Badertscher, B., B. Jorgensen, S. Katz, and W. R. Kinney. 2014. Public equity and audit pricing in the United States. Journal of Accounting Research 52 (2): 303-39.

Banerjee, S., S. Dasgupta, and Y. Kim. 2008. Buyer-supplier relationships and the stakeholder theory of capital structure. The Journal of Finance 63 (5): 2507-52.

Bauer, A. M., D. Henderson, and D. P. Lynch. 2018. Supplier internal control quality and the duration of customer-supplier relationships. The Accounting Review 93 (3): 59-82.

Behn, B. K., S. E. Kaplan, and K. R. Krumwiede. 2001. Further evidence on the auditor's going concern report: The influence of management plans. Auditing: A Journal of Practice \& Theory 20 (1): 1328.

Blay, A. 2005. Independence threats, litigation risk, and the auditor's decision process. Contemporary Accounting Research 22 (4): 759-89.

., and M. Geiger. 2013. Auditor fees and auditor independence: Evidence from going concern reporting decisions. Contemporary Accounting Research 30 (2): 579-606.

Boone, A., L. C. Field, J. Karpoff, and C. Raheja. 2007. The determinants of corporate board size and composition: An empirical analysis. Journal of Financial Economics 85 (1): 66-101.

Bruynseels, L., W. R. Knechel, and M. Willekens. 2011. Auditor differentiation, mitigating management actions, and audit-reporting accuracy for distressed firms. Auditing: A Journal of Practice \& Theory 30 (1): 1-20.

Campello, M., and J. Gao. 2017. Customer concentration and loan contract terms. Journal of Financial Economics 123 (1): 108-36.

Camuffo A., A. Furlan, and E. Rettore. 2007. Risk sharing in supplier relations: An agency model for the Italian Air-conditioning industry. Strategic Management Journal 28 (12): 1257-66.

Carson, E., N. L. Fargher, M. A. Geiger, C. S. Lennox, K. Raghunandan, and M. Willekens. 2013. Audit reporting for going concern uncertainty: A research synthesis. Auditing: A Journal of Practice \& Theory 32 (Supplement 1): 353-84.

Cen, L., S. Dasgupta, R. Elkamhi, and R. Pungaliya. 2016. Reputation and loan contract terms: The role of principal customers. Review of Finance 20 (2): 501-33.

, E. L. Maydew, L. Zhang, and L. Zuo. 2017. Customer-supplier relationships and corporate tax avoidance. Journal of Financial Economics 123 (2): 377-94.

Chen, C., X. Martin, and X. Wang. 2013. Insider trading, litigation concerns, and auditor going-concern opinions. The Accounting Review 88 (2): 365-93.

Chen, K. C. W., and B. K. Church. 1992. Default on debt obligations and the issuance of going concern opinions. Auditing: A Journal of Practice \& Theory 11 (2): 30-50.

Cohen, L., and A. Frazzini. 2008. Economic links and predictable returns. Journal of Finance 63 (4): 19772011.

Content, T. 2010. Johnson Controls selected as sole battery supplier to Wal-Mart. Journal Sentinel February 3. http://www.jsonline.com/business/83454852.html. Last accessed 5/27/2016. 
Cowley, P. R. 1988. Market structure and business performance: An evaluation of buyer/seller power in the PIMS database. Strategic Management Journal 9 (3) 271-78.

Darwin, J. 2000. Coffee plant grinds to halt. Brother Gourmet for sale after loss of big customer. Houston Business Journal November 12, 2000.

DeFond, M., K. Raghunandan, and K. R. Subramanyam. 2002. Do non-audit services fees impair auditor independence? Evidence from going concern audit opinions. Journal of Accounting Research 40 (4): 1247-74.

Degryse, H., and S. Ongena. 2005. Distance, lending relationships, and competition. Journal of Finance 60 (1): 231-66.

Dhaliwal, D., J. S. Judd, M. Serfling, and S. Shaikh. 2016. Customer concentration risk and the cost of equity capital. Journal of Accounting and Economics 61 (1): 23-48.

Diamond, D. and R. Verrecchia. 1991. Disclosure, liquidity, and the cost of capital. Journal of Finance 46 (4): 1325-59.

Dion, P., D. Easterling, and S. J. Miller. 1995. What is really necessary in successful buyer/seller relationships? Journal of Industrial Marketing Management 24 (1): 1-9.

Donovan, J., R. Frankel, J. Lee, X. Martin, and H. Seo. 2014. Issues raised by studying DeFond and Zhang: What should audit researchers do? Journal of Accounting and Economics 58 (2-3):327-38.

Dyer, J. H., and H. Singh. 1998. The relational view: Cooperative strategy and sources of interorganizational competitive advantage. Academy of Management Review 23 (4): 660- 79.

Exide. 2013. Chapter 11. Case No. 13-11482 in the United States Bankruptcy Court for the District of Delaware.

Fargher, N. L., and L. Jiang. 2008. Changes in the audit environment and auditors' propensity to issue going-concern opinions. Auditing: A Journal of Practice \& Theory 27 (2): 55-77.

FASB. 1976. Summary of Statement No. 14. Financial Accounting Standards Board. Norwalk, CT. Available online at: http://www.fasb.org/summary/stsum14.shtml. Last accessed 5/27/2016.

FASB. 1997. Statement of Financial Accounting Standards No. 131. Financial Accounting Standards Board. Norwalk, CT. Available online at: http://www.fasb.org/pdf/fas131.pdf. Last accessed $5 / 27 / 2016$.

Fee, C., and S. Thomas. 2004. Sources of gains in horizontal mergers: Evidence from customer, supplier and rival firms. Journal of Financial Economics 74 (3): 423-60.

, C. J. Hadlock, and S. Thomas. 2006. Corporate equity ownership and the governance of product market relationship. The Journal of Finance 61 (3): 1217-51.

Ference, S. B. 2015. All CPAs should be concerned about going concern. Journal of Accountancy February 1. Available online at https://www.journalofaccountancy.com/issues/2015/feb/going-concern-cpaliability.html. Last accessed 2/23/2019.

Francis, J. R., K. Reichelt, and D. Wang. 2005. The pricing of national and city-specific reputations for industry expertise in the U.S. audit market. The Accounting Review 80 (1): 113-36.

, J. R., and M. D. Yu. 2009. Big 4 office size and audit quality. The Accounting Review 84 (5): 152152.

, J. R., and P. N. Michas. 2013. The contagion effect of low quality audits. The Accounting Review 88 (2): 521-52.

Frankel, R., M. Johnson, and K. Nelson. 2002. The relation between auditors' fees for non-audit services and earnings management. The Accounting Review 77 (Supplement): 71-105.

Galbraith, J.K. 1952. American capitalism: The concept of countervailing power. Boston: Houghton Mifflin.

Ge, W., L. Tanlu, and J. L. Zhang. 2016. What are the consequences of board destaggering? Review of Accounting Studies 21 (3): 808-58.

Germain, R., and N. Spears. 1999. Quality management and its relationships with organizational context and design. International Journal of Quality \& Reliability Management 16 (4): 371-91.

Gosman, M., and M. Kohlbeck. 2009. Effects of the existence and identity of major customers on supplier profitability: Is Wal-Mart different? Journal of Management Accounting Research 21: 179-201. 
Granovetter, M. S. 1985. Economic action and social structure: The problem of embeddedness. American Journal of Sociology 91 (3): 481-510.

Grönroos, C. 2007. Service management and marketing: Customer management in service competition. Chichester, John Wiley \& Sons Ltd.

Hainmueller, J., 2012. Entropy balancing for causal effects: A multivariate reweighting method to produce balanced samples in observational studies. Political Analysis 20, 25-46.

, J., and Y. Xu. 2013. ebalance: A Stata Package for Entropy Balancing. Journal of Statistical Software, 54(7).

Hertzel, M., Z. Li, M. Officer, and K. Rodgers. 2008. Inter-firm linkages and the wealth effects of financial distress along the supply chain: Rivals, customers, and suppliers. Journal of Financial Economics 87 (2): 374-87.

Hopwood, W., J. McKeown, and J. Mutchler. 1994. A reexamination of auditor versus model accuracy within the context of the going-concern opinion decision. Contemporary Accounting Research 10 (2): 409-31.

Huang, H., G. Lobo, C. Wang, and H. Xie. 2016. Customer concentration and corporate tax avoidance. Journal of Banking and Finance 72: 184-200.

Hui, K. W., S. Klasa, and P. E. Yeung. 2012. Corporate suppliers and customers and accounting conservatism. Journal of Accounting and Economics 53 (1-2): 115-35.

IAASB. 2009. International Standard on Auditing 570: Going Concern. International Accounting and Auditing Standards Board. December 15, 2009. Available online at: http://www.ifac.org/system/files/downloads/a031-2010-iaasb-handbook-isa-570.pdf. $\quad$ Last accessed 5/27/2016.

Inderst, R., and C. Wey. 2007. Buyer power and supplier incentives. European Economic Review 51 (3): 647-67.

Iozzi, A., and T. Valletti. 2014. Vertical bargaining and countervailing power. American Economic Journal: Microeconomics 6 (3): 106-35.

Irvine, P. J., S. S. Park, and Ç. Yildizhan. 2016. Customer-base concentration, profitability, and the relationship life cycle. The Accounting Review 91 (3): 883-906.

Jackson, B. B. 1985. Winning and keeping industrial customers: The dynamics of customer relationships. Lexington, MA.

Johnstone, K. M., C. Li, and S. Luo. 2014. Client-auditor supply chain relationships, audit quality, and audit pricing. Auditing: A Journal of Practice \& Theory 33 (4): 119-66.

Jorion, P., and G. Zhang. 2009. Credit contagion from counterparty risk. The Journal of Finance 64 (5): 2053-87.

Kalwani, M., and N. Narayandas. 1995. Long-term manufacturer-supplier relationships: Do they pay off for supplier firms? Journal of Marketing 59 (1): 1-16.

Kaplan, S. E., and D. Williams. 2013. Do going concern audit reports protect auditors from litigation? A simultaneous equations approach. The Accounting Review 88 (1): 199-232.

Kennedy, P. 1992. A Guide to econometrics. Cambridge, MA: MIT Press.

Kim, Y. H. 2017. The effects of major customer networks on supplier profitability. Journal of Supply Chain Management 53 (1): 26-40

Kim, Y. H., and D. Henderson. 2015 Financial benefits and risks of dependency in triadic supply chain relationships. Journal of Operations Management 36: 115-29.

Kothari, S. P., A. J. Leone, and C. E. Wasley. 2005. Performance matched discretionary accruals. Journal of Accounting and Economics 39 (1): 163-97.

Krishnan, J., P. N. Patatoukas, and A. Y. Wang. 2018. Customer-base concentration: Implications for audit pricing and quality. Journal of Management Accounting Research. Forthcoming.

Laing, D., and C. M. Weir. 1999. Governance structures, size and corporate performance in UK firms. Management Decision 37 (5): 457-64. 
Lane, P. J., and M. Lubatkin. 1998. Relative absorptive capacity and interorganizational learning. Strategic Management Journal 19 (5): 461-77.

Lang, M., and R. Lundholm. 1993. Cross-sectional determinants of analysts' ratings of corporate disclosures. Journal of Accounting Research 31 (2): 246-71.

Lanier, D., W. F. Wempe, and Z. G. Zacharia. 2010. Concentrated supply chain membership and financial performance: Chain-and firm-level perspectives. Journal of Operations Management 28 (1): 1-16.

Lawrence, A., M. Minutti-Meza, and P. Zhang. 2011. Can Big 4 versus non-Big 4 differences in auditquality proxies be attributed to client characteristics? The Accounting Review 86 (1): 259-87.

Lian, Y. 2017. Financial distress and customer-supplier relationships. Journal of Corporate Finance 43: 397-406.

Matsumura, E. L., and J. D. Schloetzer. 2018. The structural and executional components of customer concentration: Implications for supplier performance. Journal of Management Accounting Research 30 (1): 185-202.

Minutti-Meza, M. 2013. Does auditor industry specialization improve audit quality? Journal of Accounting Research 51 (4): 779-817.

Norton, E. C., H. Wang, and C. Ai. 2004. Computing interaction effects and standard errors in logit and probit models. The Stata Journal 4 (2): 154-67.

Numan, W., and M. Willekens. 2012. An empirical test of spatial competition in the audit market. Journal of Accounting and Economics 53 (1/2): 450-65.

Ohlson, J. A. 1980. Financial ratios and the probabilistic prediction of bankruptcy. Journal of Accounting Research 18 (1): 109-31.

Pandit, S., C. E. Wasley, and T. Zach. 2011. Information externalities along the supply chain: The economic determinants of suppliers' stock price reaction to their customers' earnings announcements. Contemporary Accounting Research 28 (4): 1304-43.

Patatoukas, P. N. 2012. Customer-base concentration: Implications for firm performance and capital markets. The Accounting Review 87 (2): 363-92.

PCAOB. 2003. AU 341: The Auditor's Consideration of an Entity's Ability to Continue as a Going Concern. Public Company Accounting Oversight Board. April, 2003. Available online at: http://pcaobus.org/Standards/Auditing/Pages/AU341.aspx. Last accessed 5/27/2016.

PCAOB. 2012. Investor Sub Advisory Group: Going Concern Considerations and Recommendations. Public Company Accounting Oversight Board. March 28, 2012. Available online at: http://www.google.com/url? sa $=t \& r c t=j \& q=\& e s r c=s \&$ source=web\&cd=2\&ved=0CCUQFjAB\&ur l=http $\% 3 \mathrm{~A} \% 2 \mathrm{~F} \% 2 \mathrm{Fpcaobus} .0 \mathrm{rg} \% 2 \mathrm{FNews} \% 2 \mathrm{FEvents} \% 2 \mathrm{FDocuments} \% 2 \mathrm{~F} 03282012$ IAGMeetin g\%2FGoing_Concern_Considerations and Recommendations.pdf\&ei=5REGVNr6J8nCggSwq4 CIDw\&usg=AFQjCNEilirwtevs E7YysipXbJzKDIbVQ\&sig2=5Hp7wxNFQ1OfWhnMLqeCSg. Last accessed 5/27/2016.

Powell, C. T. 1995. Total quality management as competitive advantage: A review and empirical study. Strategic Management Journal 16 (1): 15-37.

Porter, M. E. 1980. Competitive strategy. New York: The Free Press.

Prajogo, D., and J. Olhager 2012. Supply chain integration and performance: The effects of long-term relationships, information technology and sharing, and logistics integration. International Journal of Production Economics 135 (1): 514-22.

Raman, K., and H. Shahrur. 2008. Relationship-specific investments and earnings management: Evidence on corporate suppliers and customers. The Accounting Review 83 (4): 1041-81.

Raskovich, A. 2003. Pivotal buyers and bargaining position. Journal of Industrial Economics 51 (4): 40526.

Reinartz, W. J., and V. Kumar. 2000. On the profitability of long-life customers in a noncontractual setting: an empirical investigation and implications for marketing. Journal of Marketing 64 (4): 17-35.

Reynolds, J. K., and J. R. Francis. 2001. Does size matter? The influence of large clients on office-level auditor reporting decisions. Journal of Accounting and Economics 30 (3): 375-400. 
Schumacher, U. 1991. Buyer structure and seller performance in U.S. manufacturing industries. The Review of Economics and Statistics 73 (2): 277-84.

SEC. 2015. Regulation S-K. Securities and Exchange Commission. Washington D. C. Available online at: http://www.ecfr.gov/cgi-bin/text$\underline{\mathrm{idx}}$ ?SID=8e0ed509ccc65e983f9eca72ceb26753\&node=17:3.0.1.1.11\&rgn=div5. Last accessed $5 / 27 / 2016$.

Shah, R., and P. Ward. 2003. Lean manufacturing: context, practice bundles, and performance. Journal of Operations Management 21 (2): 129-49.

Shefer, D., and A. Frenkel. 2005. R\&D, firm size and innovation: An empirical analysis. Technovation 25 (1): $25-32$.

Shipman, J. E., Q. T. Swanquist, and R. L. Whited. 2017. Propensity score matching in accounting research. The Accounting Review 92 (1): 213-44.

Short, H., and K. Keasey. 1999. Managerial ownership and the performance of firms: Evidence from the UK. Journal of Corporate Finance 5 (1): 79-101.

Snyder, C. M. 1996. A dynamic theory of countervailing power. The RAND Journal of Economics 27 (4): 747-69.

Swinney, R., and S. Netessine. 2009. Long-term contracts under the threat of supplier default. Manufacturing \& Service Operations Management 11 (1): 109-27.

Uzzi, B. 1996. The sources and consequences of embeddedness for the economic performance of organizations. American Sociological Review 61 (4): 674-98.

Wagner, E., and E. Hansen. 2005. Innovation in large versus small companies: Insights from the US wood products industry. Management Decision 43 (6): 837-50.

Weitz, B. A., S. B. Castleberry, and J. F. Tanner. 1992. Selling-building partnerships. Boston: Richard D. Irwin, Inc.

White, J. 2005. Ford to pay up to \$1.8b on Visteon. Wall Street Journal May 26 A3.

Yli-Renko, H., E. Autio. and H. J. Sapienza. 2001. Social capital, knowledge acquisition, and knowledge exploitation in young technology-based firms. Strategic Management Journal 22 (6/7): 587-613.

Zeithaml, V., M. J. Bitner, and D. Gremler. 2006. Services marketing: Integrating customer focus across the firm - International Edition. New York, NY. McGraw-Hill Irwin.

Zmijewski, M. E. 1984. Methodological issues related to the estimation of financial distress prediction models. Journal of Accounting Research 22 (Supplement): 59-82. 
TABLE 1

Sample selection

Observations available in the Compustat Segments data file where major customers and operating segments are identified from 2002 through 2010

Less:

Observations with reported segments in the Compustat Segments data file that comprise two or more customers ${ }^{28}$

Observations where the major customer is a governmental entity

Observations that voluntarily report data on customers that comprise less than $10 \%$ of total sales

Observations with missing data necessary to calculate other firm-level variables after merging with the Compustat Annual and Audit Analytics databases

Non-distressed firms (with CFO or net income greater than or equal to zero)

Final Full Sample

Number of Individual Companies

Less: Observations with missing supply chain characteristics data

Final Reduced Sample

Number of Individual Companies

${ }^{28}$ We delete these because these are operating segments that group together multiple customers rather than reflecting a single customer. 
TABLE 2

Descriptive statistics

Panel A: Full sample

\begin{tabular}{|c|c|c|c|c|c|c|}
\hline Variable & $\mathrm{N}$ & Mean & Std. Dev. & $25 \%$ & Median & $75 \%$ \\
\hline GOING CONCERN & 3,141 & .076 & .265 & 0 & 0 & 0 \\
\hline MAJ CUST SALES \% & 3,141 & .306 & .208 & .159 & .229 & .389 \\
\hline TOT CUST SALES \% & 3,141 & .422 & .261 & .192 & .360 & .619 \\
\hline HERF CUST SALES & 3,141 & .158 & .204 & .032 & .074 & .198 \\
\hline SUPP BK SCORE & 3,141 & -1.993 & 2.764 & -3.632 & -2.635 & -1.260 \\
\hline DISTANCE & 3,141 & .242 & .325 & .014 & .069 & .351 \\
\hline BIG 4 & 3,141 & .728 & .444 & 0 & 1.000 & 1.000 \\
\hline FEE RATIO & 3,141 & .184 & .169 & .049 & .137 & .278 \\
\hline OFFICE SIZE & 3,141 & 55 & 70 & 12 & 28 & 61 \\
\hline IND EXPERT & 3,141 & .292 & .454 & 0 & 0 & 1.000 \\
\hline SIZE (\$millions) & 3,141 & 640 & 1.877 & 40 & 117 & 389 \\
\hline$A B S A B A C C$ & 3,141 & .090 & .091 & .028 & .061 & .119 \\
\hline FIRM AGE & 3,141 & 12.264 & 10.511 & 5.000 & 9.000 & 16.000 \\
\hline BETA & 3,141 & 1.049 & .888 & .472 & 1.016 & 1.545 \\
\hline RETURN & 3,141 & .305 & 2.257 & -.480 & -.147 & .360 \\
\hline VOLATILITY & 3,141 & .010 & .082 & .001 & .002 & .003 \\
\hline LEVERAGE & 3,141 & .206 & .333 & .001 & .082 & .311 \\
\hline PRIOR YR LOSS & 3,141 & .726 & .445 & 0 & 1.000 & 1.000 \\
\hline INVESTMENTS & 3,141 & .353 & .277 & .101 & .300 & .580 \\
\hline DEBT ISSUE & 3,141 & .192 & .394 & 0 & 0 & 0 \\
\hline EQUITY ISSUE & 3,141 & .655 & .475 & 0 & 1.000 & 1.000 \\
\hline CFO & 3,141 & -.103 & .280 & -.159 & -.026 & .046 \\
\hline NUM OPER SEGS & 3,141 & 1.270 & 1.766 & 1.000 & 1.000 & 1.000 \\
\hline LAG GOING CONCERN & 3,141 & .049 & .215 & 0 & 0 & 0 \\
\hline
\end{tabular}

Panel B: Reduced sample

\begin{tabular}{|c|c|c|c|c|c|c|}
\hline & $\mathrm{N}$ & Mean & Std. Dev. & $25 \%$ & Median & $75 \%$ \\
\hline GOING_CONCERN & 1,395 & .068 & .252 & 0 & 0 & 0 \\
\hline MAJ_CUST_SALES_\% & 1,395 & .309 & .207 & .159 & .230 & .390 \\
\hline TOT_CUST_SALES_\% & 1,395 & .429 & .257 & .210 & .371 & .610 \\
\hline HERF_CUST_SALES & 1,395 & .161 & .203 & .035 & .077 & .203 \\
\hline SUPP_BK_SC̄ORE & 1,395 & -2.014 & 2.704 & -3.635 & -2.646 & -1.321 \\
\hline MC_BK_SCORE & 1,395 & -3.022 & 6.652 & -4.071 & -3.583 & -2.812 \\
\hline$R E L \_S I Z \bar{E} E$ & 1,395 & .029 & .221 & .001 & .003 & .011 \\
\hline REL_LENGTH & 1,395 & 2.929 & 2.224 & 1.000 & 3.000 & 4.000 \\
\hline$R E L \_A U D$ & 1,395 & .215 & .411 & 0 & 0 & 0 \\
\hline DISTANCE & 1,395 & .258 & .329 & .019 & .085 & .417 \\
\hline BIG_4 & 1,395 & .776 & .416 & 1.000 & 1.000 & 1.000 \\
\hline FEE_RATIO & 1,395 & .197 & .178 & .054 & .149 & .298 \\
\hline OFFICE_SIZE & 1,395 & 57 & 72 & 13 & 30 & 62 \\
\hline IND_EXPERT & 1,395 & .311 & .463 & 0 & 0 & 1.000 \\
\hline SIZE (\$millions) & 1,395 & 730 & 2,090 & 47 & 146 & 463 \\
\hline$A B S \_A B \_A C C$ & 1,395 & .089 & .090 & .026 & .061 & .119 \\
\hline FIRM_AGE & 1,395 & 12.125 & 10.955 & 5.000 & 10.000 & 15.000 \\
\hline BETA & 1,395 & 1.087 & .913 & .497 & 1.061 & 1.562 \\
\hline RETURN & 1,395 & .282 & 1.805 & -.486 & -.144 & .450 \\
\hline VOLATILITY & 1,395 & .010 & .099 & .001 & .002 & .003 \\
\hline LEVERAGE & 1,395 & .203 & .309 & 0 & .085 & .310 \\
\hline PRIOR_YR_LOSS & 1,395 & .715 & .451 & 0 & 1.000 & 1.000 \\
\hline INVESTMENTS & 1,395 & .363 & .270 & .118 & .322 & .580 \\
\hline DEBT_ISSUE & 1,395 & .185 & .388 & 0 & 0 & 0 \\
\hline EQUITY_ISSUE & 1,395 & .657 & .474 & 0 & 1.000 & 1.000 \\
\hline CFO & 1,395 & -.100 & .297 & -.152 & -.021 & .051 \\
\hline NUM_OPER_SEGS & 1,395 & 1.311 & 1.940 & 1.000 & 1.000 & 1.000 \\
\hline LAG_GOING_CONCERN & 1,395 & .047 & .213 & 0 & 0 & 0 \\
\hline
\end{tabular}


TABLE 2

Descriptive statistics

Panel C: Differences in major customer measures by going concern opinion

\begin{tabular}{|c|c|c|c|c|c|c|}
\hline \multirow[b]{2}{*}{ Full Sample } & \multicolumn{3}{|c|}{ GOING_CONCERN =0 } & \multicolumn{3}{|c|}{ GOING_CONCERN $=1$} \\
\hline & Mean & Median & $\mathrm{n}$ & Mean & Median & $\mathrm{n}$ \\
\hline MAJ_CUST_SALES_\% & .302 & .226 & 2,901 & $.353 * * *$ & $.289 * * *$ & 240 \\
\hline TOT_CUST_SALES_\% & .418 & .354 & 2,901 & $.477 * * *$ & $.442 * * *$ & 240 \\
\hline HERF_CUST_SALES_\% & .155 & .072 & 2,901 & $.200 * * *$ & $.110 * * *$ & 240 \\
\hline \multicolumn{7}{|l|}{ Reduced Sample } \\
\hline MAJ_CUST_SALES_\% & .305 & .230 & 1,299 & $.357 * *$ & $.297 * *$ & 96 \\
\hline TOT_CUST_SALES_\% & .426 & .370 & 1,299 & $.476 *$ & $.415 * *$ & 96 \\
\hline HERF_CUST_SALES_\% & .158 & .076 & 1,299 & $.201 * *$ & $.111 * *$ & 96 \\
\hline
\end{tabular}

***,** and * indicate significance at the $.01, .05$ and .10 respectively using two-tail tests. The Full Sample is used in Tables 3 and 4 whereas the Reduced Sample is used in Table 5, where specific supply chain characteristics are examined. See the Appendix for definitions of all variables. Bold text indicates that the mean and median values our major customer measures are significantly (.10 level or better) higher in the subsample of firms receiving a going concern opinion, relative to firms that do not receive a going concern opinion. 
TABLE 3

Greater reliance on major customers and auditor going concern audit opinions - Baseline analysis

\begin{tabular}{|c|c|c|c|}
\hline Test Variables & (1) & (2) & (3) \\
\hline MAJ_CUST_SALES_\% & $.43 * *$ & & \\
\hline TOT_CUST_SALES_\% & & $.43 * *$ & \\
\hline HERF_CUST_SALES & & & $.43 *$ \\
\hline (z-statistic) & $(2.01)$ & $(2.17)$ & $(1.92)$ \\
\hline \multicolumn{4}{|l|}{ Control Variables } \\
\hline \multirow[t]{2}{*}{ DISTANCE } & .06 & .06 & .06 \\
\hline & $(0.38)$ & $(0.35)$ & $(0.37)$ \\
\hline \multirow[t]{2}{*}{ BIG_4 } & -.01 & -.01 & -.01 \\
\hline & $(-0.11)$ & $(-0.09)$ & $(-0.08)$ \\
\hline \multirow[t]{2}{*}{ FEE_RATIO } & $-.64 * *$ & $-.61 * *$ & $-.65 * *$ \\
\hline & $(-2.05)$ & $(-1.97)$ & $(-2.07)$ \\
\hline \multirow[t]{2}{*}{ LnOFFICE_SIZE } & -.01 & -.01 & -.01 \\
\hline & $(-0.27)$ & $(-0.39)$ & $(-0.28)$ \\
\hline \multirow[t]{2}{*}{ IND_EXPERT } & .07 & .06 & .07 \\
\hline & $(0.52)$ & $(0.50)$ & $(0.52)$ \\
\hline \multirow[t]{2}{*}{ SUPP_BK_SCORE } & $.17 * * *$ & $.17 * * *$ & $.17 * * *$ \\
\hline & $(5.15)$ & $(5.10)$ & $(5.13)$ \\
\hline \multirow[t]{2}{*}{ SIZE } & $-.11 * * *$ & $-.11 * * *$ & $-.11 * * *$ \\
\hline & $(-2.67)$ & $(-2.69)$ & $(-2.72)$ \\
\hline \multirow{2}{*}{$A B S \_A B \_A C C$} & -.71 & -.73 & -.71 \\
\hline & $(-1.37)$ & $(-1.41)$ & $(-1.36)$ \\
\hline \multirow[t]{2}{*}{ FIRM_AGE } & .00 & .00 & .00 \\
\hline & $(0.01)$ & $(0.00)$ & $(0.01)$ \\
\hline \multirow[t]{2}{*}{ BETA } & .01 & .00 & .00 \\
\hline & $(0.06)$ & $(0.03)$ & $(0.08)$ \\
\hline \multirow[t]{2}{*}{ RETURN } & -.05 & -.05 & -.05 \\
\hline & $(-1.34)$ & $(-1.37)$ & $(-1.34)$ \\
\hline \multirow[t]{2}{*}{ VOLATILITY } & $.82 * *$ & $.83 * *$ & $.82 * *$ \\
\hline & $(2.11)$ & $(2.12)$ & $(2.10)$ \\
\hline \multirow[t]{2}{*}{ LEVERAGE } & $-.86 * * *$ & $-.86 * * *$ & $-.86 * * *$ \\
\hline & $(-3.36)$ & $(-3.31)$ & $(-3.34)$ \\
\hline \multirow[t]{2}{*}{ PRIOR_YR_LOSS } & $.35 * * *$ & $.35 * * *$ & $.34 * * *$ \\
\hline & $(3.09)$ & $(3.09)$ & $(3.07)$ \\
\hline \multirow[t]{2}{*}{ INVESTMENTS } & $-1.56 * * *$ & $-1.59 * * *$ & $-1.56 * * *$ \\
\hline & $(-6.39)$ & $(-6.49)$ & $(-6.38)$ \\
\hline \multirow[t]{2}{*}{ DEBT_ISSUE } & -.01 & -.01 & -.01 \\
\hline & $(-0.09)$ & $(-0.07)$ & $(-0.09)$ \\
\hline \multirow[t]{2}{*}{ EQUITY_ISSUE } & $-.43 * * *$ & $-.43 * * *$ & $-.43 * * *$ \\
\hline & $(-4.49)$ & $(-4.48)$ & $(-4.51)$ \\
\hline \multirow[t]{2}{*}{ CFO } & -.39 & -.40 & -.39 \\
\hline & $(-1.43)$ & $(-1.44)$ & $(-1.42)$ \\
\hline \multirow[t]{2}{*}{ NUM_OPER_SEGS } & .00 & .00 & .00 \\
\hline & $(-0.07)$ & $(-0.04)$ & $(0.09)$ \\
\hline \multirow[t]{2}{*}{ LAG_GOING_CONCERN } & $1.72 * * *$ & $1.71 * * *$ & $1.72 * * *$ \\
\hline & $(10.06)$ & $(10.06)$ & $(10.06)$ \\
\hline \multirow[t]{2}{*}{ INTERCEPT } & -.16 & -.21 & -.10 \\
\hline & $(-0.47)$ & $(-0.59)$ & $(-0.29)$ \\
\hline Year Fixed Effects & YES & YES & YES \\
\hline Industry Fixed Effects & YES & YES & YES \\
\hline
\end{tabular}


Area under ROC Curve

$* * *, * *$, and * indicate significance at the $.01, .05$, and .10 levels respectively using two-tail tests. Z-statistics (reported in parentheses) are calculated based on robust standards errors clustered at the firm level. See the Appendix for definitions of all variables. Bold text indicates coefficients on our major customer measures that are significant at the .10 level or better. 
TABLE 4

Greater reliance on major customers and auditor going concern audit opinions

Panel A: Full sample using supplier financial distress (SUPP_BK_SCORE) as a moderating variable

\begin{tabular}{|c|c|c|c|c|c|c|}
\hline \multirow[t]{2}{*}{ Test Variables } & \multicolumn{3}{|c|}{ Low Supplier BK Score } & \multicolumn{3}{|c|}{ High Supplier BK Score } \\
\hline & (1) & (2) & (3) & (4) & (5) & (6) \\
\hline MAJ_CUST_SALES_\% & -.37 & & & $.59 * *$ & & \\
\hline TOT_CUST_SALES_\% & & -.30 & & & $.61 * * *$ & \\
\hline HERF_CUST_SALES & & & -.24 & & & $.56 * *$ \\
\hline (z-statistic) & $(-0.66)$ & $(-0.71)$ & $(-0.38)$ & $(2.35)$ & (2.71) & $(2.24)$ \\
\hline (Chi-square statistic) & & & & $(2.30)$ & $(3.73) *$ & $(1.32)$ \\
\hline Control Variables & YES & YES & YES & YES & YES & YES \\
\hline Year Fixed Effects & YES & YES & YES & YES & YES & YES \\
\hline Industry Fixed Effects & YES & YES & YES & YES & YES & YES \\
\hline $\mathrm{N}$ & 1,659 & 1,659 & 1,659 & 1,482 & 1,482 & 1,482 \\
\hline Area under ROC Curve & .945 & .945 & .945 & .902 & .904 & .902 \\
\hline Pseudo R ${ }^{2}$ & $44.5 \%$ & $44.5 \%$ & $44.4 \%$ & $38.5 \%$ & $38.7 \%$ & $38.5 \%$ \\
\hline
\end{tabular}

Panel B: Full sample of small compared to large suppliers

\begin{tabular}{|c|c|c|c|c|c|c|}
\hline \multirow[t]{2}{*}{ Test Variables } & \multicolumn{3}{|c|}{ Small Supplier } & \multicolumn{3}{|c|}{ Large Supplier } \\
\hline & (1) & (2) & (3) & (4) & (5) & (6) \\
\hline MAJ_CUST_SALES_\% & .38 & & & $.93 * *$ & & \\
\hline TOT_CUST_SALES_\% & & .37 & & & $.72 * *$ & \\
\hline HERF_CUST_SALES & & & .38 & & & $.94 * *$ \\
\hline (z-statistic) & $(1.49)$ & $(1.51)$ & $(1.45)$ & (2.13) & (2.20) & $(2.16)$ \\
\hline (Chi-square statistic) & & & & $(1.10)$ & $(0.73)$ & $(1.08)$ \\
\hline Control Variables & YES & YES & YES & YES & YES & YES \\
\hline Year Fixed Effects & YES & YES & YES & YES & YES & YES \\
\hline Industry Fixed Effects & YES & YES & YES & YES & YES & YES \\
\hline $\mathrm{N}$ & 1,571 & 1,571 & 1,571 & 1,570 & 1,570 & 1,570 \\
\hline Area under ROC Curve & .916 & .917 & .916 & .932 & .933 & .932 \\
\hline Pseudo $\mathrm{R}^{2}$ & $41.1 \%$ & $41.1 \%$ & $41.4 \%$ & $41.7 \%$ & $41.8 \%$ & $41.6 \%$ \\
\hline
\end{tabular}

***, **, and * indicate significance at the $.01, .05$, and .10 levels respectively using two-tail tests Z-statistics (reported in parentheses unless otherwise noted) are calculated based on robust standards errors clustered at the firm level. Low Supplier BK Score and High Supplier BK Score samples are derived by median splitting the sample on SUPP_BK_SCORE. The Small Supplier and Large Supplier samples are derived by median splitting the sample on total assets. See the Appendix for definitions of all other variables. Bold text indicates coefficients on our major customer measures that are significant at the .05 level or better. 
TABLE 5

Greater reliance on major customers and auditor going concern audit opinions

Panel A: Logistic regression using sales to largest major customer scaled by supplier cost of goods sold (REL_SIZE) as a moderating variable

\begin{tabular}{lccc}
\hline Test Variables & $\mathbf{( 1 )}$ & $\begin{array}{c}\text { Large Supplier Sales to MC } \\
\text { scaled by MC COGS }\end{array}$ & $\begin{array}{c}\text { Small Supplier Sales to MC } \\
\text { scaled by MC COGS }\end{array}$ \\
\cline { 1 - 2 } $\begin{array}{l}\text { MAJ_CUST_SALES_\% } \\
\text { (z-statistic) }\end{array}$ & -.29 & $\mathbf{2})$ \\
(Chi-square statistic) & $(-0.46)$ & $\mathbf{1 . 2 2} * * *$ \\
& & $\mathbf{( 2 . 8 3 )}$ \\
Control Variables & YES & $\mathbf{( 3 . 9 9 ) * *}$ \\
Year Fixed Effects & YES & YES \\
Industry Fixed Effects & NO & YES \\
N & 697 & NO \\
Area under ROC Curve & .977 & 698 \\
Pseudo R & $64.8 \%$ & .917 \\
\hline
\end{tabular}

Panel B: Logistic regression using the length of the relationship with the largest major customer (REL_LENGTH) as a moderating variable

\begin{tabular}{lcc}
\hline Test Variables & Short Relationship (<= 3 Years) & Long Relationship (>3 Years) \\
\cline { 1 - 3 } \cline { 3 - 3 } MAJ_CUST_SALES_\% & $\mathbf{( 1 )}$ & $\mathbf{( 2 )}$ \\
(z-statistic) & $\mathbf{. 7 5 *}$ & $\mathbf{- 2 . 3 6 * *}$ \\
(Chi-square statistic) & $\mathbf{( 1 . 6 3 )}$ & $\mathbf{( - 2 . 1 0 )}$ \\
& & $\mathbf{( 6 . 5 3 ) * *}$ \\
Control Variables & & YES \\
Year Fixed Effects & YES & YES \\
Industry Fixed Effects & YES & YES \\
N & YES & 412 \\
Area under ROC Curve & 983 & .992 \\
Pseudo R & .924 & $78.9 \%$ \\
\hline
\end{tabular}


TABLE 5

Greater reliance on major customers and auditor going concern audit opinions

Panel C: Logistic regression using whether the largest major customer and supplier are audited by the same audit firm (REL_AUD) as a moderating variable.

Test Variables

$\overline{\text { Test Variables }}$

MAJ_CUST_SALES_\%

(z-statistic)

(Chi-square statistic)

Control Variables

Year Fixed Effects

Industry Fixed Effects

$\mathrm{N}$

Area under ROC Curve

Pseudo $\mathrm{R}^{2}$
Same Audit Firm

(1)

-1.88 *

(-1.82)

\begin{tabular}{l}
\hline YES \\
NO \\
NO \\
298 \\
.959 \\
$51.2 \%$
\end{tabular}

Different Audit Firm

(2)

$1.24 * * *$

(3.20)

(8.06) $* * *$

YES

YES

NO

1,097

.944

$47.5 \%$

$* * *, * *$, and * indicate significance at the $.01, .05$, and .10 levels respectively using two-tail tests. Z-statistics (reported in parentheses unless otherwise noted) are calculated based on robust standards errors clustered at the firm level. Large Supplier Sales to MC scaled by MC COGS and Small Supplier Sales to MC scaled by MC COGS samples are derived by median splitting the sample on REL_SIZE using all sample firms with required data. The Short Relationship and Long Relationship samples are derived by median splitting the sample on REL_LENGTH. The Same Audit Firm sample is comprised of supplier firms that have the same audit firm as their largest major customer. The Different Audit Firm sample is comprised of supplier firms that do not have the same audit firm as their largest major customer. See the Appendix for definitions of all other variables. Bold text indicates coefficients on our major customer measures that are significant at the .10 level or better. 